\title{
Veterinary Antimicrobials in Cattle Feedlot Environs and Irrigation Conveyances in a High-Intensity Agroecosystem in Southern Alberta, Canada
}

Srinivas Sura ( $\nabla$ srinivas.sura@AGR.GC.CA)

Agriculture and Agri-Food Canada https://orcid.org/0000-0001-5419-6406

Francis J. Larney

Agriculture and Agri-Food Canada

Jollin Charest

Alberta Ministry of Agriculture and Forestry

Tim A. McAllister

Agriculture and Agri-Food Canada

John V. Headley

Environment Canada: Environment and Climate Change Canada

Allan J. Cessna

Agriculture and Agri-Food Canada

\section{Research Article}

Keywords: Veterinary antimicrobial, Surface water, Beef cattle, Manure, Irrigation, Intensive agroecosystem, Alberta

Posted Date: March 8th, 2022

DOI: https://doi.org/10.21203/rs.3.rs-1387427/v1

License: (우 This work is licensed under a Creative Commons Attribution 4.0 International License. Read Full License 


\section{Abstract}

The South Saskatchewan River Basin (SSRB) is considered one of the most intensively farmed regions in Canada, with high densities of livestock and expansive areas of irrigated cropland. We measured concentrations of seven veterinary antimicrobials (VAs) in 114 surface water samples from feedlot environs and 219 samples from irrigation conveyances in the SSRB. Overall, detection frequencies in feedlot environs were $100 \%$ for chlortetracycline (CTC) and tetracycline (TC), $94 \%$ for monensin (MON), $84 \%$ for tylosin (TYL), $72 \%$ for lincomycin (LIN), 66\% for erythromycin (ERY), and 23\% for sulfamethazine (SMZ). For irrigation conveyances, detection frequencies for CTC and TC remained high (94-100\%), but dropped to $18 \%$ for ERY, $15 \%$ for TYL, $10 \%$ for MON, and $4 \%$ for SMZ. Lincomycin was not detected in irrigation conveyance water. High detection frequencies and median concentrations of VAs in both feedlot environs and irrigation conveyances were associated with high amounts of precipitation. However, an irrigation district (ID) with high livestock density (Lethbridge Northern) did not exhibit higher concentrations of VAs compared to IDs with less livestock, while levels of VAs in irrigation conveyances were less influenced by the degree of surface runoff. The ubiquity of CTC and TC in our study is likely a reflection of its widespread use in intensive livestock operations. Additional investigation is required to link environmental concentrations of VAs with livestock densities, and increase our understanding of potential antimicrobial resistance in high-intensity agroecosystems.

\section{Introduction}

In southern Alberta, the South Saskatchewan River Basin (SSRB) comprises the Oldman, Bow, Red Deer, and a portion of the South Saskatchewan River sub-basins (Fig. 1a). The rivers generally flow eastward from the Rocky Mountains, through the foothills and prairie, with a combined watershed area of $121,000 \mathrm{~km}^{2}$ in Alberta. The climate is semiarid with annual precipitation ranging from $900 \mathrm{~mm}$ in the sub-alpine west, to $300 \mathrm{~mm}$ in mixed grassland in the east. Except for the upper reaches in the mountains and foothills, the SSRB is considered one of the most intensively farmed regions in Canada due to high densities of beef cattle (grazing, confined feeding operations), dairy, swine, and poultry; and the largest area of irrigated cropland in the country (Schindler and Donahue, 2006; Alberta Environment, 2006; Alberta Agriculture and Forestry, 2021).

In 2015, Alberta had 5.2 million head of cattle (Statistics Canada, 2016), or $42 \%$ of Canada's national cattle herd, and ranked fourth in North America, after Texas (11.7 million), Nebraska (6.5 million), and Kansas (6.3 million) [USDA, 2020]. In addition, Alberta had 1.4 million swine and 14.9 million poultry. The majority of Alberta's intensive livestock industry (i.e., confined feeding operations, including beef cattle feedlots) is located in the SSRB, largely due to access to irrigation for production of livestock feed (silage, hay, forage, grain) and a favorable climate. In recent decades, Lethbridge County, in the Oldman sub-basin of the SSRB, has had the highest number of animal units (e.g., 427,000 in 2001) in Canada (Beaulieu and Bedard, 2003).

Veterinary antimicrobials (VAs) are widely administered to livestock, therapeutically for treatment of infection, and sub-therapeutically for disease prevention (Sarmah et al. 2006). Van Boeckel et al. (2015) estimated global average annual consumption of VAs $\left(\mathrm{kg}^{-1}\right.$ of animal produced) at $45 \mathrm{mg} \mathrm{kg}^{-1}$ for cattle, 
$148 \mathrm{mg} \mathrm{kg}^{-1}$ for chicken, and $172 \mathrm{mg} \mathrm{kg}^{-1}$ for swine. Excretion rates in manure (feces and urine) may approach 95\% (Kim et al., 2011), depending on the VA, its dose, growth stage and species of livestock (Zhou et al., 2013). The presence of VAs in aquatic environments depends not only on their physico-chemical properties but also on veterinary and agricultural practices, climate conditions, and landscape characteristics such as soil type, slope, and buffer zones (Jaffrézic et al., 2017). Land application of manure is a major point of entry of VAs to the broader agroecosystem, leading to (i) contamination of surface and groundwater (Kümmerer, 2009; Lapworth et al., 2012); (ii) potential uptake by crops destined for human consumption (Azanu et al, 2016; Tasho and Cho, 2016); and (iii) selection for pathogenic bacteria harbouring antimicrobial resistance genes (Heuer et al., 2011; Chattopadhyay, 2014), which may reduce the therapeutic efficacy of antimicrobials against bacterial infections in humans and animals (Landers et al., 2012). From 1981 to 2001, seven of the ten sub-sub-drainage areas showing the largest increases (1.6-4.1 $\mathrm{Mg} \mathrm{ha}^{-1}$ ) in manure production in Canada were in the SSRB (Statistics Canada, 2006). Cattle (beef, dairy) generated $>90 \%$ of the manure, with lesser amounts from swine and poultry.

In 2015, Alberta had $28 \%$ of Canada's total cropland and $71 \%$ of Canada's irrigated cropland (Statistics Canada, 2016). Land use intensity and input requirements are higher under irrigation than dryland farming, due to higher yields, greater crop diversification, and avoidance of drought (Irrigation Water Management Study Committee, 2002). Almost $98 \%$ of Alberta's irrigation occurs within the SSRB (Paterson Earth \& Water Consulting, 2015), most of which ( 566,000 ha) is managed by about 6,000 farmers within 13 irrigation districts (ID). Irrigation within the SSRB relies on surface water from spring snowmelt in the Rocky Mountains which is stored in on-stream and off-stream reservoirs, with a total capacity of $\sim 3$ billion $\mathrm{m}^{3}$, and delivered through $\sim 8,000 \mathrm{~km}$ of conveyance networks of canals and pipelines (Paterson Earth \& Water Consulting, 2015). Water is not only supplied to irrigated crops, but also to livestock, rural residents for household use, and municipalities for swimming pools, parks, and industrial use, including food processing. Water stored in irrigation reservoirs provides wildlife habitat and recreational opportunities such as fishing, boating, and camping (Irrigation Water Management Study Committee, 2002).

The occurrence of VAs in aquatic environments (surface and groundwater) has been widely reported (Alonso et al., 2019; Couperus et al., 2016; Danner et al. 2019; Felis et al., 2020). In an analysis of 247 water samples from 23 Alberta watersheds, Forrest et al. (2011) detected chlortetracycline (CTC), sulfamethazine (SMZ), monensin (MON), lincomycin (LIN), erythromycin (ERY), and other VAs. In southern Alberta, Sura et al. (2015) reported maximum runoff estimates based on simulation of a one in 100-yr rainfall event of 1.3$3.6 \mathrm{~g} \mathrm{head}^{-1}$ of CTC, $1.9 \mathrm{~g} \mathrm{head}^{-1}$ of SMZ, and $0.2 \mathrm{~g} \mathrm{head}^{-1}$ of tylosin (TYL), to catch basins from beef cattle feedlot pens. After land application of feedlot manure in southern Alberta, Amarakoon et al. (2014) reported mass losses in surface runoff of CTC > SMZ > TYL, (expressed as a percent of amounts applied), which were independent of their respective soil sorption coefficients ( $K \mathrm{~d}$ values). Moreover, Amarakoon et al. (2016) measured CTC in soil 10 months after manure application and found that there was a potential risk for build-up of VA residues if feedlot manure was repeatedly applied to the same land. Kuchta et al. (2009) showed that LIN in manure can persist in the environment for several months and percolate into groundwater. Furthermore, Leung et al. (2013) reported median concentrations of $10 \mathrm{ng} \mathrm{L}^{-1}$ for SMZ, and 6 $n g L^{-1}$ for TYL in tap water in China, while TYL was also found in drinking water in France at 4-20 ng L-1 
(Charuaud et al. 2019), signifying the potential for these VAs to move from farming environments to drinking water despite application of water treatment.

In Alberta, the Water Act (Province of Alberta, 1999) shifted the focus from supply management to protection of aquatic and riparian ecosystems, and sustainable resource development. As such, water quality protection is a main thrust of Alberta's irrigation strategy (Alberta Agriculture and Forestry, 2020). However, surface water used for irrigation has, to date, not been analyzed for the presence of VAs. Recognizing that the SSRB represents one of the most intensively farmed agroecosystems in Canada, the objectives of this study were to measure concentrations of VAs in surface water associated with (i) beef cattle feedlot environs; and (ii) irrigation conveyances, within the river basin.

\section{Materials And Methods}

\section{Feedlot environs}

Two beef cattle feedlots with production practices typical of western Canada were selected for water sampling. Cattle were confined in open-air, earthen-floor pens arranged side-by-side with central feed alleys. In line with provincial regulations, feedlots had runoff control catch basins (CB) with storage capacities to accommodate 1 in 30-yr rainfall events in $24 \mathrm{~h}$, and solid manure storage and collection areas at setback distances > 30 m from common water bodies (Alberta Agriculture and Rural Development, 2008).

Feedlot A (18,000 head capacity) was located in the Oldman River Basin (Fig. 1a) and previously described by Tymensen et al. (2017). Briefly, surface runoff water from two-thirds of the pens drained to a large catch basin (CB-1, Fig. 1b), with remaining pens draining to a smaller catch basin (CB-2, Fig. 1b). Accumulated water in $\mathrm{CB}-2$ was periodically transferred to a primary retention pond (PRP), or to CB-1. From the PRP, water was transferred to a 2-ha constructed wetland (CW) consisting of two parallel cells populated by cattail (Typha latifolia). After retention in the $\mathrm{CW}$, water flow was directed via a grassed waterway to a secondary retention pond (SRP). The land adjacent to the feedlot was used for corn (Zea mays L.) or barley (Hordeum vulgare L.) silage production, and received annual manure applications, and intermittent irrigation with runoff water from CB-1, or water from the SRP. This land drained naturally into an ephemeral creek flowing east (Fig. 1b) at $\sim 100 \mathrm{~m}$ south of the feedlot.

Feedlot B (15,000 head capacity) was in the Red Deer River Basin in south-central Alberta (Fig. 1a). A catch basin (CB) was situated $\sim 50 \mathrm{~m}$, and an ephemeral creek $\sim 100 \mathrm{~m}$, west of the feedlot pens (Fig. 1c). Feedlot $B$ was surrounded by pastureland. At Feedlots $A$ and $B$, water samples were collected between April and October (Table 1) each year (2014-16), because surface water is often frozen in southern Alberta during the late fall and winter. 
Table 1

Sampling dates and sites for veterinary antimicrobials in feedlot environs, 2014-16.

Feedlot A

$\begin{array}{llllll}\text { Site } & \text { CB-1 } & \text { CB-2 } & \text { PRP } & \text { CW } & \text { SRP } \\ \text { Creek-D }\end{array}$
Feedlot B

CB Creek-U Creek-D

$$
2014
$$

Date

$14 \mathrm{Ap}$

$28 \mathrm{Ap}$

28

25

20

$$
15
$$

$\begin{array}{ll}15 \text { Sep } & 1 \\ 28 \text { Oct } & 1\end{array}$

--------------------- 2015

Date

$27 \mathrm{Ap}$

19 May 1

22

27

$$
24
$$

5 Oct 1

\begin{tabular}{cccc}
$0^{\mathrm{b}}$ & 1 & 1 & 1 \\
1 & 1 & 1 & 1 \\
\hline
\end{tabular}

2015 


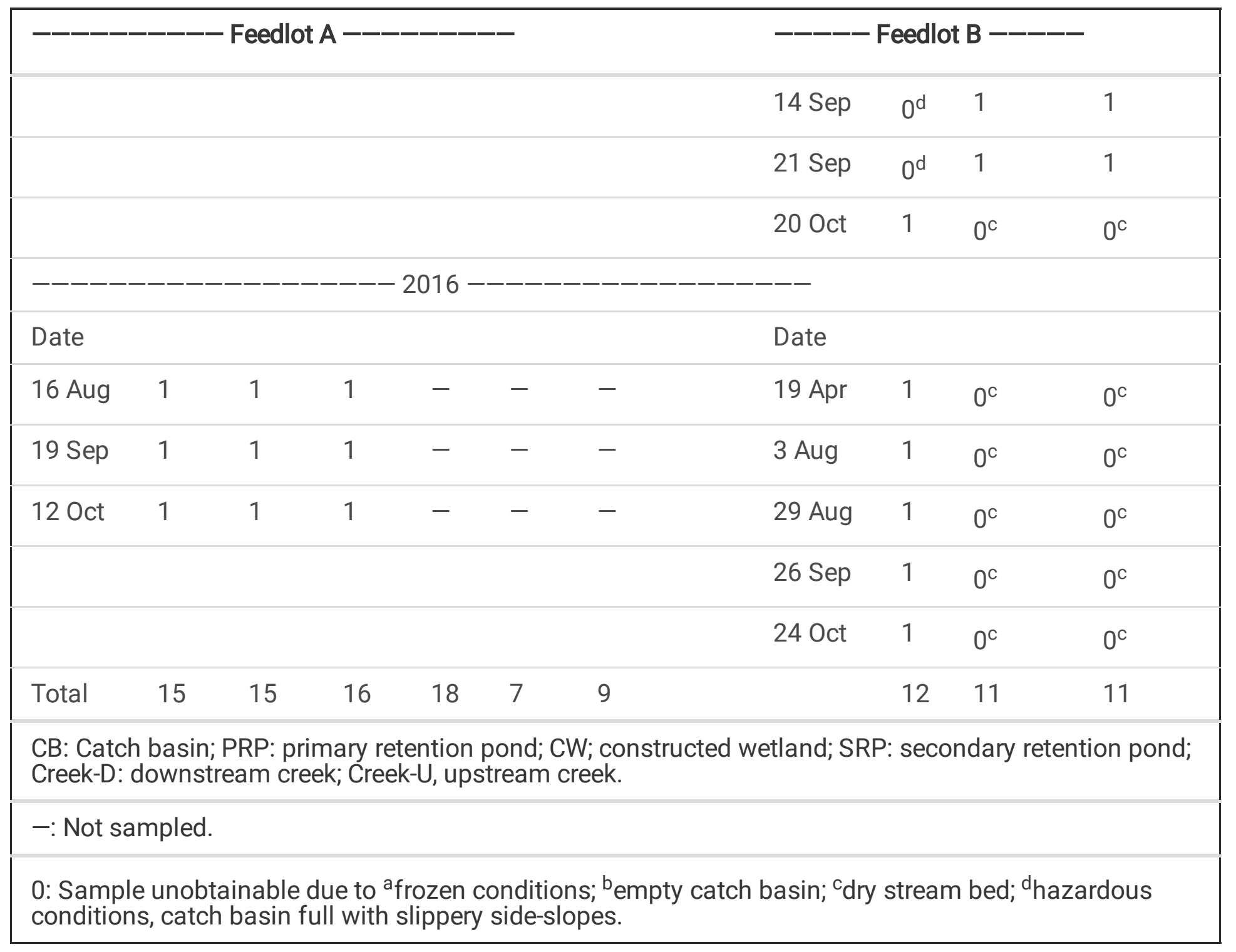

\section{Irrigation Conveyances}

Surface water sampling of irrigation conveyances was part of an Irrigation Districts Water Quality (IDWQ) project which assessed the quality of irrigation water within IDs in the SSRB (Charest et al. 2015). The IDWQ project ran for 5-yr (2011-15), with salinity and concentrations of nutrients, metals, pathogens, and pesticides measured at 90 sampling sites spanning all thirteen IDs. Sampling sites fell into three conveyance categories: primary, secondary and return (Charest et al. 2015). Primary sites were main canals where source water entered an ID, while secondary sites were canals that branched off the main canal, or were immediately downstream of a reservoir. Return sites were located at the end of an ID conveyance network, where water was no longer used for irrigation, and allowed to return to the natural drainage system. Within return sites, there were two sub-categories: (i) infrastructure returns, i.e., constructed canals, generally not influenced by surface runoff; (ii) watershed returns, i.e., natural channels that collected surface runoff from adjacent irrigated land. 
Veterinary antimicrobial analyses were added to the IDWQ project in 2013-15 only, using subsets of sampling sites: a preliminary subset of 15 sites in 7 IDs in 2013; followed by the same 15, plus a further 9 sites $(n=24)$ in 8 IDs in both 2014 and 2015 (Table 2). The Lethbridge Northern, St. Mary River, Taber, Bow River, Eastern, and Western IDs (Fig. 2) were expected to have higher levels of VAs due the presence of intensive livestock operations, especially Lethbridge Northern as it encompasses the highest density of beef cattle in Canada (Acharya et al. 2007). The remaining two IDs [United, and Mountain View (2014-15 only); Fig. 2] were in the less agriculturally intensive southwestern part of the SSRB (Alberta Environment, 2007). These sites were envisioned as 'controls', with expected lower VAs concentrations due to (i) proximity to pristine headwaters from the Rocky Mountains and (ii) livestock production predominantly grazing, rather than confined feeding operations. Only secondary and return sites were chosen for VAs analyses within irrigation conveyances due to greater potential of detecting VAs because of proximity to farmland. Table 2 shows the number of sampling sites within each ID, and their designations (secondary; watershed return; infrastructure return). The origin of samples by ID was: $20 \%$ Lethbridge Northern; $18 \%$ St. Mary River; $13 \%$ Taber, Bow River, and Western; 12\% Eastern; and 11\% United-Mountain View. The origin by conveyance category was $37 \%$ secondary; $32 \%$ infrastructure return; and $31 \%$ watershed return. 
Table 2

Number of veterinary antimicrobial sampling sites (with number of samples collected in parentheses) within the South Saskatchewan River Basin from 2013-15.

\begin{tabular}{|c|c|c|c|c|c|}
\hline \multirow[t]{2}{*}{ Irrigation district } & \multirow[t]{2}{*}{ Year } & \multicolumn{3}{|c|}{-----_ Conveyance category --_--- } & \multirow[t]{2}{*}{ Total } \\
\hline & & Secondary & Infrastructure return & Watershed return & \\
\hline \multirow[t]{4}{*}{ Lethbridge Northern } & 2013 & $1(2)^{\mathrm{a}}$ & $1(2)$ & $1(2)$ & $3(6)$ \\
\hline & 2014 & $2(8)$ & $1(4)$ & $2(8)$ & $5(20)$ \\
\hline & 2015 & $2(8)$ & $1\left(3^{c}\right)$ & $2(8)$ & $5(19)$ \\
\hline & Sub-total & $5(18)$ & $3(9)$ & $5(18)$ & $13(45)$ \\
\hline \multirow[t]{4}{*}{ St. Mary River } & 2013 & $-b$ & $2\left(3^{d}\right)$ & $2(4)$ & $4(7)$ \\
\hline & 2014 & $-b$ & $2(8)$ & $2(8)$ & $4(16)$ \\
\hline & 2015 & $-b$ & $2(8)$ & $2(8)$ & $4(16)$ \\
\hline & Sub-total & $-b$ & $6(19)$ & $6(20)$ & $12(39)$ \\
\hline \multirow[t]{4}{*}{ Taber } & 2013 & $2(4)$ & $-b$ & $-b$ & $2(4)$ \\
\hline & 2014 & $2(8)$ & $1(4)$ & $-b$ & $3(12)$ \\
\hline & 2015 & $2(8)$ & $1(4)$ & $-b$ & $3(12)$ \\
\hline & Sub-total & $6(20)$ & $2(8)$ & $-b$ & $8(28)$ \\
\hline \multirow[t]{4}{*}{ Bow River } & 2013 & $1(2)$ & $-b$ & $1(2)$ & $2(4)$ \\
\hline & 2014 & $2(8)$ & $-b$ & $1(4)$ & $3(12)$ \\
\hline & 2015 & $2(8)$ & $-b$ & $1(4)$ & $3(12)$ \\
\hline & Sub-total & $5(18)$ & $-b$ & $3(10)$ & $8(28)$ \\
\hline \multirow[t]{4}{*}{ Eastern } & 2013 & $-b$ & $-b$ & $1(2)$ & $1(2)$ \\
\hline & 2014 & $1(4)$ & $1(4)$ & $1(4)$ & $3(12)$ \\
\hline & 2015 & $1(4)$ & $1(4)$ & $1(4)$ & $3(12)$ \\
\hline & Sub-total & $2(8)$ & $2(8)$ & $3(10)$ & $7(26)$ \\
\hline
\end{tabular}

aValues in parentheses represent number of water samples collected based on two samplings site ${ }^{-1}$ (June, August) in in 2013, and four samplings site ${ }^{-1}$ (June, July, August, September) in 2014 and 2015. b`_'no sample collected. One site not sampled: ' June 2015; 'June 2013; ' September 2015. 


\begin{tabular}{|c|c|c|c|c|c|}
\hline \multirow{2}{*}{$\begin{array}{l}\text { Irrigation district } \\
\text { Western }\end{array}$} & \multirow{2}{*}{$\begin{array}{l}\text { Year } \\
2013\end{array}$} & \multicolumn{3}{|c|}{ ーーーーーー Conveyance category ーーーーーー } & \multirow{2}{*}{$\begin{array}{l}\text { Total } \\
2(4)\end{array}$} \\
\hline & & $1(2)$ & $-b$ & $1(2)$ & \\
\hline & 2014 & $2(8)$ & $-b$ & $1(4)$ & $3(12)$ \\
\hline & 2015 & $2(8)$ & $-b$ & $1(4)$ & $3(12)$ \\
\hline & Sub-total & $5(18)$ & $-b$ & $3(10)$ & $8(28)$ \\
\hline \multirow[t]{4}{*}{ United } & 2013 & $-b$ & $1(2)$ & $-b$ & $1(2)$ \\
\hline & 2014 & $-b$ & $2(8)$ & $-b$ & $2(8)$ \\
\hline & 2015 & $-b$ & $2(8)$ & $-b$ & $2(8)$ \\
\hline & Sub-total & $-b$ & $5(18)$ & $-b$ & $5(18)$ \\
\hline \multirow[t]{4}{*}{ Mountain View } & 2013 & $-b$ & $-b$ & $-b$ & $-b$ \\
\hline & 2014 & $-b$ & $1(4)$ & $-b$ & $1(4)$ \\
\hline & 2015 & $-b$ & $1\left(3^{\mathrm{e}}\right)$ & $-b$ & $1(3)$ \\
\hline & Sub-total & $-b$ & $2(7)$ & $-b$ & $2(7)$ \\
\hline Grand total & & $23(82)$ & $20(69)$ & $20(68)$ & 63 (219) \\
\hline \multicolumn{6}{|c|}{$\begin{array}{l}\text { aValues in parentheses represent number of water samples collected based on two samplings site }{ }^{-1} \\
\text { (June, August) in in } 2013 \text {, and four samplings site }{ }^{-1} \text { (June, July, August, September) in } 2014 \text { and } 2015 .\end{array}$} \\
\hline
\end{tabular}

\section{Water Sample Collection}

Over the 3 year (2014-16), 80 surface water samples were collected from Feedlot A, and 34 from Feedlot B, resulting in a total of 114 samples (Table 1). In 2014, there were six sampling sites at Feedlot A: CB-1, CB-2, PRP, CW, SRP, and the ephemeral creek, $2.6 \mathrm{~km}$ downstream (Creek-D) from the feedlot (Fig. 1b, Table 1). For the CW, four locations per cell were collected and composited into one sample. In 2015, two samples were collected from the CW, one from each cell, except on 24 August, when only one cell was sampled (Table 1). The SRP site was dropped from the study in 2015 (Table 1) due to potential variation in water quality, because water flow into the SRP not only originated from the $\mathrm{CW}$, but also intermittently from the PRP via overland flow. In 2014 and 2015, not all sites were sampled on each date (Table 1) at Feedlot A, due to frozen or dry catch basins, or a dry ephemeral creek. In 2016, sampling at Feedlot A was confined to only three sites (CB-1, CB-2, PRP), later in the season (Table 1). 
Feedlot $B$ had three sampling sites: the catch basin (CB); and sites on the ephemeral creek located $\sim 1.6 \mathrm{~km}$ upstream (Creek-U), and $~ 1.5 \mathrm{~km}$ downstream (Creek-D), from the feedlot (Fig. 1c, Table 1). Due to dry conditions, samples could not be collected from the CB on some dates in 2014 and 2015, or from the ephemeral creek in all 3 year.

For irrigation conveyances, water sampling campaigns extended to 3-4 d to complete all 90 sites of the larger IDWQ project. Samples were collected twice in 2013 (11-13 June; 27-29 August); four times in 2014 (10-12 June; 7-10 July; 5-7 August; 2-4 September); and four times in 2015 (8-11 June; 6-9 July; 2730 July, 31 August-September 3) [Table 2]. For year-to year comparisons, sampling times were designated by month. Since two samplings occurred in July 2015, the latter one (27-30 July) was assigned to August.

Water samples were collected mid-depth using 1-L polyethylene bottles attached to a telescopic pole. At feedlots, water from four locations sampling site ${ }^{-1}$ was deposited into a clean plastic pail, from which $1 \mathrm{~L}$ was funnelled into amber glass bottles. At irrigation conveyances, 1-L samples were collected mid-channel and transferred into 1-L amber glass bottles. In the field, water samples were placed in iced coolers and then refrigerated at $4^{\circ} \mathrm{C}$ prior to transport to the National Hydrology Research Centre, Environment and Climate Change Canada, Saskatoon, SK. Samples were extracted for VAs within $24-48 \mathrm{~h}$ after arrival at the laboratory.

\section{Target Veterinary Antimicrobials}

Six VAs were quantified in irrigation conveyance water samples in 2013: CTC, SMZ, TYL, MON, LIN, and ERY. Analysis of a seventh VA, tetracycline (TC), was added for all 2014 and 2015 samples (feedlot and irrigation conveyance), and 2016 feedlot samples. Among the seven analyzed, four VAs were administered to cattle at Feedlots A and B (CTC, SMZ, TYL, MON), while three were not (LIN, ERY, TC).

\section{Sample Analyses}

Water samples were subjected to solid phase extraction (Supplementary material S1) followed by liquid chromatography tandem mass spectrometry (LC-MS-MS) for detection and quantification of VAs concentrations (Supplementary material S2). The limits of quantification (LOQ) for each analyte are shown in Table S2.

\section{Precipitation Data}

For feedlots, daily precipitation data were obtained from weather stations (Alberta Climate Information Service, 2020) located closest to Feedlot A $(14 \mathrm{~km})$ and Feedlot B $(12.8 \mathrm{~km})$. For IDs, one centrally located weather station in each of the eight IDs was chosen, and mean precipitation estimated.

\section{Statistical Analyses}


Concentrations of VAs falling between 50 and $100 \%$ of LOQ $\left(2.5-5 \mathrm{ng} \mathrm{L}^{-1}\right)$ were assigned values equivalent to the MDL (method detection limit, $2.5 \mathrm{ng} \mathrm{L}^{-1}$, or $50 \%$ of the LOQ), and were included in statistical analyses performed by SigmaPlot (Systat Software Inc., 2020). Concentrations $<$ MDL were considered undetectable and excluded from statistical analyses.

For feedlot samples, concentrations of VAs were pooled for statistical comparisons between the three years (2014-16), the seven sampling months (April-October), and the three sample sources [catch basin (CB1, $C B 2$, Feedlot $A ; C B$, Feedlot $B$ ), retention pond/wetland (PRP, CW, and SRP, Feedlot A), and creek (Creek-U, Feedlot $A ;$ Creek-U and Creek D, Feedlot B)]. For irrigation conveyances, VA concentration data were pooled for comparisons between the 10 sampling times (8 for TC), seven IDs (data from the United and Mountain View IDs amalgamated as a control), and three conveyance category/sub-categories (secondary site, infrastructure return, watershed return). Data were compared using side-by-side box plots which generated descriptive statistics as well as visual interpretation. The Kruskal-Wallis test was used to identify significant differences between median VA concentrations. A non-parametric one-way ANOVA was selected because VAs concentrations were not always normally distributed. Following a significant Kruskal-Wallis test $(p<$ 0.05), pairwise multiple comparison analyses were performed with a post-hoc Dunn's test. Median concentrations of VAs were compared between upstream and downstream creek locations at Feedlot B using the Mann-Whitney rank sum test. The Mann-Whitney rank sum test was also used to compare median VA concentrations of feedlot environ samples to irrigation conveyance samples.

\section{Results And Discussion Feedlot environs}

Overall, detection frequency in feedlot water samples was $100 \%$ for CTC and TC, followed by $94 \%$ for MON, $84 \%$ for TYL, $72 \%$ for LIN, $66 \%$ for ERY, and $23 \%$ for SMZ (Table 3). Sulfamethazine showed the highest proportions of samples with MDL-LOQ detections $(11 \%)$, or undetectable $(66 \%)$. The proportion of samples undetectable for LIN and ERY ranged from 23-26\% (Table 3). Maximum concentrations (Table 4) ranked from 1,384 $\mathrm{\mu g} \mathrm{L}^{-1}$ for TC (PRP, Feedlot A; 27 July 2015), to 5,215 $\mathrm{ng} \mathrm{L}^{-1}$ for MON (SRP, Feedlot A; 28 October 2014), 4,861 ng L ${ }^{-1}$ for CTC (CB-1, Feedlot A; 5 October 2015), $951 \mathrm{ng} \mathrm{L}^{-1}$ for TYL (SRP, Feedlot A; 28 October 2014), $166 \mathrm{ng} \mathrm{L}^{-1}$ for ERY (CW, Feedlot A; 15 September 2014), $117 \mathrm{ng} \mathrm{L}^{-1}$ for LIN (Creek-U,

Feedlot B; 14 April 2014), and $17 \mathrm{ng} \mathrm{L}^{-1}$ for SMZ (CB-2, Feedlot A; 24 August 2015)]. Median concentrations followed the same order, ranging from $531 \mathrm{ng} \mathrm{L}^{-1}$ for CTC to $6 \mathrm{ng} \mathrm{L}^{-1}$ for SMZ (Table 5). Minimum concentrations were < LOQ for four VAs (SMZ, TYL, LIN, ERY), while CTC (Creek-D, Feedlot A; 28 April 2014) and MON (Creek-D, Feedlot B; 8 April 2015) both had minimum concentrations of $5.6 \mathrm{ng} \mathrm{L}^{-1}$ (Table 4). The minimum concentration observed for TC was $13 \mathrm{ng} \mathrm{L}^{-1}$ (Creek-D, Feedlot B; 28 April 2014). 
Table 3

Detection frequency parameters of seven antimicrobials in water samples from feedlot environs, 2014 to 2016.

\begin{tabular}{|c|c|c|c|c|c|c|c|c|c|c|}
\hline Sample group & $\begin{array}{l}\text { Samples, } \\
n\end{array}$ & СтC & SMZ & TYL & MON & LIN & ERY & TC & $\begin{array}{l}\text { Overall } \\
\text { mean }^{a}\end{array}$ & $\begin{array}{l}\text { No. VAs } \\
\text { detected }\end{array}$ \\
\hline & & \multicolumn{8}{|c|}{ 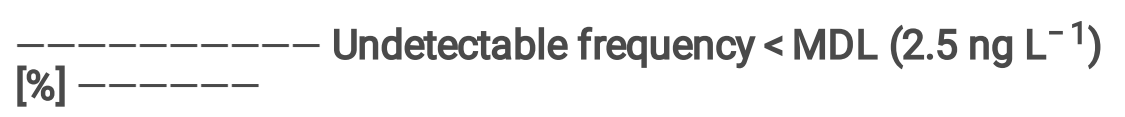 } & \\
\hline \multirow[t]{2}{*}{ All } & 114 & 0 & 66 & 8 & 6 & 23 & 26 & 0 & 18 & \\
\hline & & \multicolumn{8}{|c|}{$\begin{array}{l}--------- \text { Detection frequency MDL-LOQ }\left(2.5-5 \mathrm{ng} \mathrm{L}^{-}\right. \\
\text {1) [\%] ------ }\end{array}$} & \\
\hline \multirow[t]{2}{*}{ All } & 114 & 0 & 11 & 8 & 0 & 5 & 8 & 0 & 5 & \\
\hline & & \multicolumn{8}{|c|}{---------- Detection frequency > LOQ $\left(5 \mathrm{ng} \mathrm{L}^{-1}\right)[\%]$} & \\
\hline All & 114 & 100 & 23 & 84 & 94 & 72 & 66 & 100 & 77 & 7 \\
\hline \multicolumn{11}{|l|}{ Year } \\
\hline 2014 & 52 & 100 & 33 & 81 & 94 & 87 & 71 & 100 & 81 & 7 \\
\hline 2015 & 51 & 100 & 16 & 84 & 92 & 61 & 53 & 100 & 72 & 7 \\
\hline 2016 & 11 & 100 & 9 & 100 & 100 & 55 & 100 & 100 & 81 & 7 \\
\hline \multicolumn{11}{|l|}{ Month } \\
\hline April & 27 & 100 & 15 & 85 & 85 & 48 & 22 & 100 & 65 & 7 \\
\hline May & 16 & 100 & 13 & 87 & 100 & 81 & 88 & 100 & 81 & 7 \\
\hline June & 18 & 100 & 0 & 83 & 100 & 83 & 100 & 100 & 81 & 6 \\
\hline July & 10 & 100 & 70 & 90 & 100 & 100 & 90 & 100 & 93 & 7 \\
\hline August & 11 & 100 & 27 & 100 & 100 & 73 & 55 & 100 & 79 & 7 \\
\hline September & 15 & 100 & 20 & 60 & 80 & 53 & 60 & 100 & 68 & 7 \\
\hline October & 17 & 100 & 41 & 88 & 100 & 88 & 77 & 100 & 85 & 7 \\
\hline
\end{tabular}

aBased on 7 analyses (CTC, SMZ, TYL, MON, LIN, ERY, TC) of 114 samples $(n=7 \times 114=798)$.

${ }^{b}$ Includes Catch basins 1 and 2 (CB-1, CB2), Feedlot A; and catch basin (CB), Feedlot B.

Includes primary retention pond (PRP), constructed wetland (CW), and secondary retention pond (SRP) at Feedlot $\mathrm{A}$.

${ }^{\mathrm{d}}$ Includes Creek-downstream (Creek-D), Feedlot A; and Creek-downstream (Creek-D) and upstream (Creek-U) at Feedlot B. 


\begin{tabular}{|c|c|c|c|c|c|c|c|c|c|c|}
\hline Sample group & $\begin{array}{l}\text { Samples, } \\
n\end{array}$ & СтC & SMZ & TYL & MON & LIN & ERY & TC & $\begin{array}{l}\text { Overall } \\
\text { mean }^{a}\end{array}$ & $\begin{array}{l}\text { No. VAs } \\
\text { detected }\end{array}$ \\
\hline \multicolumn{11}{|l|}{ Source } \\
\hline Catch basin ${ }^{b}$ & 42 & 100 & 31 & 98 & 100 & 76 & 81 & 100 & 84 & 7 \\
\hline $\begin{array}{l}\text { Retention } \\
\text { pond/wetland }\end{array}$ & 41 & 100 & 32 & 93 & 100 & 85 & 71 & 100 & 83 & 7 \\
\hline Creek $^{d}$ & 31 & 100 & 0 & 55 & 77 & 48 & 39 & 100 & 60 & 6 \\
\hline \multicolumn{11}{|c|}{ a'Based on 7 analyses (CTC, SMZ, TYL, MON, LIN, ERY, TC) of 114 samples $(n=7 \times 114=798)$. } \\
\hline \multicolumn{11}{|c|}{${ }^{\mathrm{b}}$ Includes Catch basins 1 and 2 (CB-1, CB2), Feedlot A; and catch basin (CB), Feedlot B. } \\
\hline \multicolumn{11}{|c|}{$\begin{array}{l}\text { CIncludes primary retention pond (PRP), constructed wetland (CW), and secondary retention pond (SRP) } \\
\text { at Feedlot A. }\end{array}$} \\
\hline $\begin{array}{l}\text { dIncludes Creek } \\
\text { (Creek-U) at Fee }\end{array}$ & $\begin{array}{l}\text { wnstream } \\
\text { t B. }\end{array}$ & eek & Fees & A; $a$ & Creek & wns & $\mathrm{m}$ & k-D & nd upst & \\
\hline
\end{tabular}


Table 4

Summary statistics for concentrations of seven antimicrobials in feedlot environs and irrigation conveyances.

\begin{tabular}{|c|c|c|c|c|c|c|c|}
\hline Statistic & СтC & SMZ & TYL & MON & LIN & ERY & TC \\
\hline & \multicolumn{7}{|c|}{-ーーーーーーーー Feedlot environs ${ }^{\mathrm{a}}\left(\mathrm{ng} \mathrm{L}^{-1}\right)$-ーーーーーーーーーーー } \\
\hline Maximum & 4,861 & 17 & 951 & 5,215 & 117 & 166 & $1,384,822$ \\
\hline \multicolumn{8}{|l|}{ M } \\
\hline Median & 277 & 6.0 & 42 & 436 & 14 & 9.9 & 531 \\
\hline Mean & 479 & 6.9 & 114 & 801 & 19 & 23 & 50,010 \\
\hline Minimum & 5.6 & $<\mathrm{LOQ}$ & $<\mathrm{LOQ}$ & 5.6 & $<\mathrm{LOQ}$ & $<\mathrm{LOQ}$ & 13 \\
\hline 10th percentile & 35 & $<\mathrm{LOQ}$ & 5.2 & 14 & 5.4 & $<\mathrm{LOQ}$ & 92 \\
\hline 25th percentile & 113 & $<\mathrm{LOQ}$ & 10 & 116 & 8.1 & 6.8 & 300 \\
\hline 75th percentile & 537 & 9.6 & 132 & 938 & 27 & 25 & 1,950 \\
\hline \multirow[t]{2}{*}{ 90th percentile } & 1001 & 13 & 324 & 2,842 & 39 & 49 & 11,045 \\
\hline & \multicolumn{7}{|c|}{ ーーーーーーーー Irrigation conveyances ${ }^{b}\left(\mathrm{ng} \mathrm{L}^{-1}\right)$} \\
\hline Maximum & 69 & 33 & 117 & 31 & $<\mathrm{LOQ}$ & 29 & 155 \\
\hline \multicolumn{8}{|l|}{ M } \\
\hline Median & 25 & 5.5 & $<\mathrm{LOQ}$ & $<\mathrm{LOQ}$ & $<\mathrm{LOQ}$ & 5.6 & 56 \\
\hline Mean & 27 & 9.7 & 15 & 4.8 & $<\mathrm{LOQ}$ & 6.7 & 59 \\
\hline Minimum & $<\mathrm{LOQ}$ & $<\mathrm{LOQ}$ & $<\mathrm{LOQ}$ & $<\mathrm{LOQ}$ & $<\mathrm{LOQ}$ & $<\mathrm{LOQ}$ & 19 \\
\hline 10th percentile & 10 & $<\mathrm{LOQ}$ & $<\mathrm{LOQ}$ & $<\mathrm{LOQ}$ & $<\mathrm{LOQ}$ & $<\mathrm{LOQ}$ & 28 \\
\hline 25th percentile & 17 & $<\mathrm{LOQ}$ & $<\mathrm{LOQ}$ & $<L O Q$ & $<$ LOQ & $<$ LOQ & 37 \\
\hline 75th percentile & 35 & 17 & 7.9 & 6.1 & $<\mathrm{LOQ}$ & 9.9 & 76 \\
\hline 90th percentile & 47 & 30 & 70 & 8.9 & $<\mathrm{LOQ}$ & 13 & 92 \\
\hline \multicolumn{8}{|c|}{ aBased on 114 water samples. } \\
\hline${ }^{\mathrm{b}}$ Based on $219 \mathrm{v}$ & er ca & $s(1$ & $\mathrm{rTC})$. & & & & \\
\hline
\end{tabular}


Table 5

Detection frequency of seven antimicrobials in water samples from irrigation conveyances, 2013 to 2015.

\begin{tabular}{|c|c|c|c|c|c|c|c|c|c|c|}
\hline Sample group & $\begin{array}{l}\text { Samples, } \\
n^{\mathrm{a}}\end{array}$ & Стс & SMZ & TYL & MON & LIN & ERY & TC & $\begin{array}{l}\text { Overall } \\
\text { mean }^{b}\end{array}$ & $\begin{array}{l}\text { No. VAs } \\
\text { detected }\end{array}$ \\
\hline & & \multicolumn{8}{|c|}{ 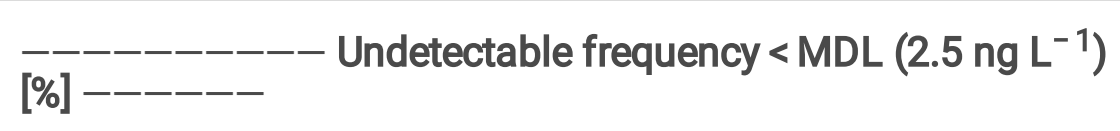 } & \\
\hline \multirow[t]{2}{*}{ All } & $\begin{array}{l}219 \\
(190)\end{array}$ & 1 & 94 & 59 & 69 & 93 & 69 & 0 & 56 & \\
\hline & & \multicolumn{8}{|c|}{$\begin{array}{l}--------- \text { Detection frequency MDL-LOQ }\left(2.5-5 \mathrm{ng} \mathrm{L}^{-}\right. \\
\text {1) [\%] ------- }\end{array}$} & \\
\hline All & $\begin{array}{l}219 \\
(190)\end{array}$ & 5 & 2 & 26 & 21 & 7 & 13 & 0 & 11 & \\
\hline & & \multicolumn{8}{|c|}{ 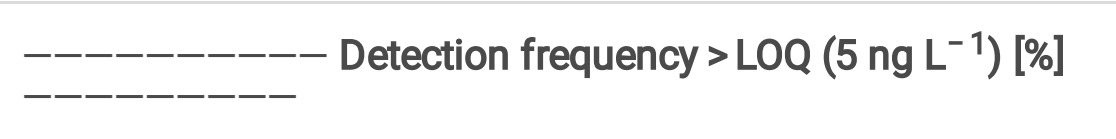 } & \\
\hline All & $\begin{array}{l}219 \\
(190)\end{array}$ & 94 & 4 & 15 & 10 & 0 & 18 & 100 & 33 & 6 \\
\hline \multicolumn{11}{|l|}{ Date } \\
\hline Jun 2013 & 14 & 93 & 0 & 93 & 14 & 0 & 71 & $-^{c}$ & 45 & 4 \\
\hline Aug 2013 & 15 & 40 & 27 & 100 & 0 & 0 & 100 & $-^{c}$ & 44 & 4 \\
\hline Jun 2014 & 24 & 100 & 0 & 0 & 0 & 0 & 13 & 100 & 30 & 3 \\
\hline Jul 2014 & 24 & 100 & 0 & 0 & 0 & 0 & 8 & 100 & 30 & 3 \\
\hline Aug 2014 & 24 & 100 & 0 & 0 & 13 & 0 & 0 & 100 & 30 & 3 \\
\hline Sep 2014 & 24 & 100 & 0 & 4 & 8 & 0 & 38 & 100 & 36 & 5 \\
\hline Jun 2015 & 23 & 100 & 0 & 4 & 22 & 0 & 0 & 100 & 32 & 4 \\
\hline Jul 2015 & 24 & 92 & 13 & 4 & 13 & 0 & 0 & 100 & 32 & 4 \\
\hline Aug 2015 & 24 & 100 & 0 & 0 & 13 & 0 & 0 & 100 & 30 & 3 \\
\hline Sep 2015 & 23 & 100 & 4 & 13 & 22 & 0 & 0 & 100 & 34 & 5 \\
\hline
\end{tabular}

aTC in parentheses.

${ }^{\mathrm{b}}$ Based on 6 analyses (CTC, SMZ, TYL, MON, LIN, ERY) of 219 samples and 1 analysis (TC) of 190 samples $[n=(6 \times 219)+(1 \times 190)=1504]$.

CNot analyzed. 


\begin{tabular}{|c|c|c|c|c|c|c|c|c|c|c|}
\hline Sample group & $\begin{array}{l}\text { Samples, } \\
n^{\mathrm{a}}\end{array}$ & СТC & SMZ & TYL & MON & LIN & ERY & $\mathrm{TC}$ & $\begin{array}{l}\text { Overall } \\
\text { mean }\end{array}$ & $\begin{array}{l}\text { No. VAs } \\
\text { detected }\end{array}$ \\
\hline $\begin{array}{l}\text { Lethbridge } \\
\text { Northern }\end{array}$ & $45(39)$ & 91 & 2 & 13 & 2 & 0 & 27 & 100 & 32 & 6 \\
\hline St. Mary River & $39(32)$ & 92 & 0 & 23 & 8 & 0 & 21 & 100 & 33 & 5 \\
\hline Taber & $28(24)$ & 96 & 7 & 18 & 21 & 0 & 18 & 100 & 36 & 6 \\
\hline Bow River & $28(24)$ & 96 & 4 & 14 & 25 & 0 & 18 & 100 & 35 & 6 \\
\hline Eastern & $26(24)$ & 96 & 12 & 12 & 4 & 0 & 15 & 100 & 33 & 6 \\
\hline Western & $28(24)$ & 96 & 4 & 18 & 11 & 0 & 7 & 100 & 32 & 6 \\
\hline $\begin{array}{l}\text { United- } \\
\text { Mountain } \\
\text { View }\end{array}$ & $25(23)$ & 96 & 0 & 8 & 8 & 0 & 12 & 100 & 31 & 5 \\
\hline \multicolumn{11}{|c|}{ Conveyance category } \\
\hline Secondary & $82(72)$ & 96 & 6 & 15 & 11 & 0 & 15 & 100 & 34 & 6 \\
\hline $\begin{array}{l}\text { Infrastructure } \\
\text { return }\end{array}$ & $69(62)$ & 94 & 3 & 12 & 12 & 0 & 17 & 100 & 33 & 6 \\
\hline $\begin{array}{l}\text { Watershed } \\
\text { return }\end{array}$ & $68(56)$ & 93 & 1 & 21 & 9 & 0 & 22 & 100 & 33 & 6 \\
\hline \multicolumn{11}{|c|}{${ }^{\mathrm{a}} \mathrm{TC}$ in parentheses. } \\
\hline \multicolumn{11}{|c|}{$\begin{array}{l}\text { b Based on } 6 \text { analyses (CTC, SMZ, TYL, MON, LIN, ERY) of } 219 \text { samples and } 1 \text { analysis (TC) of } 190 \\
\text { samples }[n=(6 \times 219)+(1 \times 190)=1504] \text {. }\end{array}$} \\
\hline${ }^{c}$ Not analyzed. & & & & & & & & & & \\
\hline
\end{tabular}

Since CTC and TC were both detected at $100 \%$, there was no temporal or spatial variation in their detection frequencies (Table 3). Comparing 2014 and 2015 [years with similar numbers of samples $(n=51-52)$ ], SMZ detection frequency was higher in 2014 (33\%) than 2015 (16\%), as were LIN (87 vs. 61\%), and ERY (71 vs. 53\%)[Table 3]. Sampling year was significant for median concentrations of TYL (Fig. 4c), LIN (Fig. 4e), ERY (Fig. 4f), and TC (Fig. 4g), but not CTC (Fig. 4a), SMZ (Fig. 4b) or MON (Fig. 4d). For TYL (Fig. 4C), both 2014 and 2016 had significantly higher median concentrations $\left(61-85 \mathrm{ng} \mathrm{L}^{-1}\right)$ than $2015\left(23 \mathrm{ng} \mathrm{L}^{-1}\right)$. 2014 was also significantly higher for $\operatorname{LIN}\left(\tilde{x}=20 \mathrm{ng} \mathrm{L}^{-1}\right)$ than $2015\left(10 \mathrm{ng} \mathrm{L}^{-1}\right)$ [Fig. 4e], as was ERY (26 vs. $7 \mathrm{ng} \mathrm{L}^{-1}$ ) [Fig. 4f]. At Feedlot A, May-June precipitation in 2014 totaled $139 \mathrm{~mm}$, compared to $73 \mathrm{~mm}$ in 2015 (Fig. 3a). At Feedlot B, precipitation in May-June 2014 (Fig. 3b) was double (156 mm) that of 2015 $(78 \mathrm{~mm})$. This may explain the higher detection frequencies of SMZ, LIN and ERY ( $\bar{x}=64 \%)$ in 2014, than $2015(\bar{x}=43 \%)$, and significantly higher median concentrations of TYL, LIN, and ERY in 2014 ( $\bar{x}=36 \mathrm{ng} \mathrm{L}^{-}$ $\left.{ }^{1}\right)$, than $2015\left(\bar{x}=13 \mathrm{ng} \mathrm{L}^{-1}\right)$. Higher precipitation likely led to greater surface runoff from (i) feedlot pen floors and bedding packs, which is collected in catch basins (Miller et al., 2004), and (ii) manured land 
which contributed to VAs in creek settings. Little et al. (2007) found that the majority of surface runoff in Alberta occurred in spring, coinciding with land application of fresh manure, just prior to seeding, when soil is not frozen or snow-covered. TC was different in that 2015 had a significantly higher median concentration $\left(1.96 \mu \mathrm{g} \mathrm{L}^{-1}\right)$ than both 2014 and $2016\left(0.36-0.98 \mu \mathrm{g} \mathrm{L}^{-1}\right)$ [Fig. 4g].

Monthly variation in detection frequency was most evident for SMZ, varying from $0 \%$ in June, to $70 \%$ in July (Table 3). April detections were lowest for both LIN (48\%) and ERY (22\%), before increasing to $100 \%$ for ERY in June, and for LIN in July, and then falling to 55\% for ERY in August, and 53\% for LIN in September (Table 3). Overall, April showed the lowest detection frequency (65\%), while frequencies increased from May-June (81\%) through July (93\%) [Table 3]. The lower detection frequency in April (65\%) was matched by significantly lower concentrations of CTC, TYL, MON, ERY, and TC in April than in other months. For example, April was significantly lower than June, July and October for CTC (46 vs. 290-513 ng L-1; Fig. 4a); October for both TYL (28 vs. $89 \mathrm{ng} \mathrm{L}^{-1}$; Fig. 4c) and MON (260 vs. $656 \mathrm{ng} \mathrm{L}^{-1}$; Fig. 4d), September for ERY (7 vs. $39 \mathrm{ng} \mathrm{L}^{-1}$; Fig. 4f), and July for TC (0.13 vs. $447 \mu \mathrm{g} \mathrm{L}^{-1}$; Fig. $\left.4 \mathrm{~g}\right)$. This was attributed to precipitation patterns (Fig. 3) and associated runoff, with mean April precipitation $76 \%$ lower $(\bar{X}=14 \mathrm{~mm} ; 2$ feedlots $\times 3$ year, $n=6)$ than May-September $(\bar{x}=59 \mathrm{~mm} ; 5 \mathrm{mo} \times 2$ feedlots $\times 3$ year, $n=30)$. These findings agreed with Hyland et al. (2003), who showed that fecal contamination in surface waters from the Oldman River Basin was lower during winter than summer months (May-September). In an intensively agricultural watershed in Nebraska, highest mean concentrations of MON (49 ng L-1) and LIN (68 ng L-1) also occurred in summer months (Jaimes-Correa et al. 2015). Sampling month was non-significant for median concentrations of SMZ (2.5-12 ng L ${ }^{-1}$; Fig. 4b), and LIN (8-22 ng L ${ }^{-1}$; Fig. 4e).

Detection frequencies were similar for samples sourced from catch basin and retention ponds/wetland for SMZ (31-32\%), TYL (93-98\%), and MON (100\%), while creeks were zero for SMZ, or substantially lower for TYL (55\%) and MON (77\%) [Table 3]. Creeks also showed lower detection frequencies of both LIN and ERY $(39-48 \%)$, compared to catch basins or retention ponds/wetland (71-85\%). The lower detection frequencies in creeks than feedlot catch basins, or retention ponds/wetland was expected, because runoff carrying VAs from feedlot pens should not be entering creeks, if catch basins are performing optimally, and best management practices are followed.

Four VAs showed significant effects of feedlot sample source on median concentrations: CTC (Fig. 4a), TYL (Fig. 4C), MON (Fig. 4d), and TC (Fig. 4g). Only CTC showed a significant downward trend from catch basin (525 $\left.\mathrm{ng} \mathrm{L}^{-1}\right)$, to retention ponds/wetland $\left(295 \mathrm{ng} \mathrm{L}^{-1}\right)$, to creek $\left(99 \mathrm{ng} \mathrm{L}^{-1}\right.$ ) [Fig. 4 a]. The $44 \%$ reduction in median concentration of CTC in retention ponds/wetland samples, compared to catch basin samples, showed that the CW played a role in mitigating CTC levels. In addition, Tymensen et al. (2017) isolated significantly fewer enterococci and $E$. coli from the CW compared to catch basin $\mathrm{B}$, which was the input source for the wetland. Constructed wetlands are globally recognized as a treatment technology for many types of wastewater (Vymazal, 2011, llyas et al., 2020). The elimination of VAs from CWs can be achieved through physicochemical decomposition, photodegradation, adsorption by wetland soil and plants, and microbial biodegradation (Choi et al., 2016), with removal efficiencies of 20-50\% (Almeida et al., 2013; Li et al., 2014). Cessna et al. (2020) reported $\mathrm{DT}_{50}$ (time required for $50 \%$ dissipation) values of $3.3 \mathrm{~d}$ for $\mathrm{CTC}, 7$ 
d for SMZ, and $14 \mathrm{~d}$ for LIN for Canadian prairie wetlands. However, in our study, apart from CTC, none of the other VAs (SMZ, TYL, MON, LIN, ERY, TC) showed evidence of removal in the CW, with no significant difference between concentrations in catch basin vs. retention ponds/wetland samples. For three VAs, creek water was significantly lower than both catch basin and retention ponds/wetland: 7 vs. $43-88 \mathrm{ng} \mathrm{L}^{-1}$ for TYL (Fig. 4C); 19 vs. $456-731$ ng L $^{-1}$ for MON (Fig. 4d); and 0.36 vs. $0.59-0.69 \mu \mathrm{g} \mathrm{L}^{-1}$ for TC (Fig. $4 \mathrm{~g}$ ). Concentrations of the remaining VAs were not significantly affected by feedlot sample source, with median values falling within narrow ranges: SMZ, 2.5-7 $\mathrm{ng} \mathrm{L}^{-1}$ (Fig. 4b); LIN, 10-17 $\mathrm{ng} \mathrm{L}^{-1}$ (Fig. 4e), and ERY, 9$24 \mathrm{ng} \mathrm{L}^{-1}$ (Fig. 4f).

For the creek at Feedlot B, higher downstream vs. upstream detection frequency for TYL (73 vs. 36\%) and MON (82 vs. 64\%) [Table S3], did not lead to significantly higher downstream concentrations of these VAs. In fact, none of six detected VAs showed a creek location effect $(P=0.15-0.83)$ on median concentration, which was unanticipated, as degradation of water quality (e.g., increased nutrient and pathogen loads), linked to intensive livestock production, has been widely reported within the SSRB (Byrne et al., 2006; Johnson et al., 2003; Jokinen et al., 2012). Our results point to possible entry of VAs further upstream than our sampling location, or a limited contribution of Feedlot B to overall VAs loads in the adjacent creek.

\section{Irrigation Conveyances}

For irrigation conveyance samples, overall detection frequencies ranked from ubiquitous (100\%) for TC, to $94 \%$ for CTC, with substantially lower detection frequencies for ERY (18\%), TYL (15\%), MON (10\%), and SMZ (4\%) (Table 5). Lincomycin was undetectable (<LOQ) in irrigation conveyance water. Substantial proportions of conveyance samples analyzed for TYL $(26 \%)$ and MON $(21 \%)$ fell into the MDL-LOQ detection category (used in statistical analyses of concentration data).

Rankings for maximum concentrations were of the order: $155 \mathrm{ng} \mathrm{L}^{-1}$ for TC (secondary site, Bow River ID, September 2014), $117 \mathrm{ng} \mathrm{L}^{-1}$ for TYL (secondary site, Western ID, September 2014), $69 \mathrm{ng} \mathrm{L}^{-1}$ for CTC (watershed return, Bow River ID, September 2014), $33 \mathrm{ng} \mathrm{L}^{-1}$ for SMZ (infrastructure return, Eastern ID, July 2015), $31 \mathrm{ng} \mathrm{L}^{-1}$ for MON (watershed return, Western ID, June 2013), and $29 \mathrm{ng} \mathrm{L}^{-1}$ for ERY (secondary site, Taber ID, June 2013) [Table 4]. It was noteworthy, that maximum concentrations of three VAs (CTC, TYL, TC) occurred in the September 2014 sampling, and two VAs (MON, ERY) in the June 2013 sampling. The 21-d precipitation in the SSRB prior to and including sampling days (Table S4) was 78-79 $\mathrm{mm}$ for the September 2014 and June 2013 samplings, substantially higher than all other samplings (3-34 mm).

Sampling time had a significant effect on median concentrations of CTC (Fig. 5a), SMZ (Fig. 5b), TYL (Fig. 5c), ERY (Fig. 5e), and TC (Fig. 5f), but not MON (Fig. 5d). For CTC, both 2013 samplings were significantly lower $\left(\tilde{x}=2.5-15 \mathrm{ng} \mathrm{L}^{-1}\right)$ than all other samplings $\left(20-41 \mathrm{ng} \mathrm{L}^{-1}\right)$, except September 2015 (19 $\mathrm{ng} \mathrm{L}^{-1}$ ) [Fig. 5a]. Comparing median concentrations in equivalent months, September 2014 was significantly higher than September 2015, for both CTC (37 vs. $19 \mathrm{ng} \mathrm{L}^{-1}$, Fig. 5a) and TC (84 vs. $36 \mathrm{ng} \mathrm{L}^{-1}$, Fig. 5f). This was likely explained by higher 21-d precipitation prior to September $2014(78 \mathrm{~mm})$ than September 2015 (29 mm) samplings [Table S4]. Also for TC (Fig. 5f), 80\% higher 1 May-31 July 
precipitation (Table S4) in 2014 (196 mm), than $2015(109 \mathrm{~mm})$, in the SSRB, likely explained a 60\% higher mean median concentration for June-August 2014 (69 ng L-1) vs. June-August 2015 (43 ng L $\left.{ }^{-1}\right)$. These findings agreed with other studies where higher VA concentrations were recorded under high flow conditions associated with high seasonal rainfall and surface runoff (Forrest et al., 2011; Jaimes-Correa et al., 2015). In southern Alberta, Gannon et al. (2005) suggested aggregation and accumulation of particulate bacteria in sediments that accumulated in areas of low water flow, e.g., slow-moving stretches of rivers, and behind weirs and dams in irrigation conveyances. However, during spring runoff and following summer storm events, increased flow rates and scouring within the drainage system contributed to increased bacterial contamination of surface water. The same mechanism may be true for VAs.

However, not all effects on VAs detection frequencies and concentrations were explained by precipitation and its influence on surface runoff. For example, the August 2013 sampling had the lowest 21-d precipitation (3 $\mathrm{mm}$, Table S4), yet produced 100\% detection frequencies, and significantly higher median concentrations of TYL (70 ng L $\left.{ }^{-1}\right)$ than June, July and September $2015\left(\tilde{x}=2.5 \mathrm{ng} \mathrm{L}^{-1}\right)$ [Fig. 5c], and ERY $\left(\tilde{X}=11 \mathrm{ng} \mathrm{L}^{-1}\right)$ than July and September $2014\left(\tilde{X}=2.5 \mathrm{ng} \mathrm{L}^{-1}\right)$ [Fig. 5e], as well as the highest detection frequency (27\%) of SMZ (Table 5). This agreed with Alonso et al. (2019) who found higher MON concentrations with low rainfall conditions. Conversely, with high rainfall, they reported greater runoff and higher discharge in rivers, which increased solute dilution, and favored chemical and microbiological degradation. Kolok et al. (2014) suggested that sediment serves as both a sink and source, equilibrating with VAs during storm events, then slowly releasing them back into water over time, long after the initial pulse of VAs has moved downstream. In contrast, August 2013 produced the lowest detection frequency (40\%, Table 5) and median concentration (2.5 ng $\mathrm{L}^{-1}$, Fig. 5a) of CTC in the study.

Spatially, CTC detection frequencies were 91-92\% for the Lethbridge Northern and St. Mary River IDs, and $96 \%$ for the remaining IDs in the study (Table 5). Detection frequency of SMZ ranged from 12\% (Eastern ID) to zero > LOQ (St. Mary River and United-Mountain View), while TYL was lowest for United-Mountain View (8\%), with other IDs somewhat higher (12-23\%). For MON, the Taber and Bow River IDs were higher (21$25 \%)$ than others (2-11\%). The Lethbridge Northern ID had highest detection frequency of ERY (27\%), while Western ID was lowest (7\%). Overall, across 7 VAs, there was only slight variation in mean detection frequencies, ranging from 31\% for United-Mountain View, to 36\% for Taber.

It was expected that IDs with higher intensive livestock production would show greater detection frequencies of VAs. However, apart from the highest detection frequency of ERY (27\%), Lethbridge Northern ID (home to 'Feedlot Alley') had the lowest detection frequencies of CTC (91\%) and MON (2\%), the second lowest of SMZ (2\%), and the third lowest of TYL (13\%) [Table 5]. Previous studies in the SSRB also failed to draw statistically significant relationships between intensive livestock production and water quality (Johnson et al., 2003; Little et al., 2003). Hyland et al. (2003) and Little et al. (2003) attributed increased bacterial contamination of surface water following precipitation events to aspects other than animal density, e.g., runoff topology of the landscape, and farm-specific practices, such as animal grazing and stream access, and the timing and rate of manure application, factors which likely also apply to VA contamination. 
Irrigation district was significant for CTC (Fig. 6a) and TC (Fig. 6f), but non-significant for SMZ, TYL, MON, and ERY median concentrations (Figs. 6b-e). For CTC, the median concentration in the Bow River ID was significantly greater (32 $\mathrm{ng} \mathrm{L}^{-1}$ ) than that in the United-Mountain View IDs (22 $\left.\mathrm{ng} \mathrm{L}^{-1}\right)$ [Fig. 6a]. For TC, there was a similar finding, with the Bow River ID being significantly higher $\left(\tilde{X}=73 \mathrm{ng} \mathrm{L}^{-1}\right)$ than UnitedMountain View (42 $\left.\mathrm{ng} \mathrm{L}^{-1}\right)$, as well as the Western ID $\left(44 \mathrm{ng} \mathrm{L}^{-1}\right)$ [Fig. 6f]. As such, the 'control' UnitedMountain View IDs, chosen to represent less intensive livestock production, with fewer and smaller confined feeding operations, and more extensive cattle grazing, showed significantly lower median concentrations of CTC (by 31\%), and TC (by 42\%) than the Bow River ID. While this behavior was somewhat anticipated for the United-Mountain View IDs, the Lethbridge Northern ID rather than the Bow River ID was expected to be significantly higher. While the Bow River ID has beef cattle feedlots, their size and density is less than the Lethbridge Northern ID, while dairy and swine operations are also less common. Unfortunately, livestock statistics in Alberta are only available for counties or rural municipalities, rather than IDs, so direct relationships between livestock numbers in an ID and VA concentrations are difficult to generate.

Compared to sampling time and ID, conveyance category had limited influence on detection frequency (Table 5), varying by only 3-5 percentage points for CTC (93-96\%), MON (9-12\%), and SMZ (1-6\%). Across all 7 VAs, however, detection frequency was almost identical (33-34\%) for the three conveyance categories. However, even though both TYL and ERY showed slight increases in detection frequencies between secondary conveyances (15\%) and watershed returns (21-22\%) [Table 5], this did not follow through to median concentrations, with conveyance category non-significant $(P=0.25-0.91)$ for all six VAs (Fig. 6). This finding was somewhat unexpected as watershed returns are natural channels, which collect excess water (runoff) from irrigation, as well as natural drainage flow, and occasionally ditch water, or municipal effluent (Charest et al. 2015). Most of the water flow in watershed returns originates from within an ID, and without irrigation, many would be dry in summer. Infrastructure returns are constructed canals at the end of an IDs infrastructure, and are therefore generally less influenced by surface runoff. In southern Alberta, Little et al. (2003) showed that irrigation returns had higher concentrations of dissolved P, total N, and $E$. coli, suggesting an impact of livestock manure. Similarly, Charest et al (2014) observed a general increase in the concentrations of salts, nutrients, and pathogens from the primary to secondary to return sites, and most water quality parameter concentrations were higher in watershed returns than in infrastructure returns. However, in line with our results, Cessna et al. (2001) showed only minor effects of nutrients from irrigation returns on receiving water bodies. Furthermore, Charest and et al. (2015) studied the impact of irrigation returns on rivers and concluded that the effect was negligible.

\section{Veterinary Antimicrobials In A High-intensity Agroecosystem}

Tetracycline was the only VA with $100 \%$ detection frequency in both feedlot and irrigation conveyance samples. Chlortetracycline was a close second with $100 \%$ detection frequency in feedlot environs and $94 \%$ in irrigation conveyances. Daghrir and Drogui (2013) reported that tetracycline antimicrobials were most widely used globally for veterinary and human therapy. In addition, Mompelat et al. (2009) reported excretion rates of $80-90 \%$ for TC, compared with only 5-10\% for ERY, while physico-chemical properties of TC defined its hydrophilic character, with high water solubility, and lower octanol-water partition 
coefficients $\left(K_{\mathrm{ow}}\right)$. Also, a relatively low Henry's constant indicated that TC was weakly lost via volatilization. For four VAs, detection frequencies were substantially lower for irrigation conveyances vs. feedlot samples: 4 vs. $23 \%$ for SMZ; 15 vs. $84 \%$ for TYL; 10 vs. $94 \%$ for MON; and 18 vs. $66 \%$ for ERY. Lincomycin was the only VA detected in feedlot environs that was undetectable $(<\mathrm{LOQ})$ in irrigation conveyance water.

As well as manure application, transport pathways to explain the ubiquity of TC, and to a lesser extent CTC in our study, include entry to surface water via runoff, following discharge of catch basin contents onto cropland through irrigation systems. This practice is widely employed, including at Feedlot A (Tymensen et al. 2017), especially if catch basins reach capacity during months of highest precipitation (May-July). In addition, until recently, airborne transport of VAs to downwind aquatic systems was given little consideration (McEachran et al., 2015). In Texas, Sandoz et al. (2018) found a significant relationship between distance to nearest cattle feedyard and MON concentration in wetlands. They pointed out that while aerial VAs transport may be minimal in humid regions with moderate to high rainfall, it was potentially a major pathway in semiarid regions. Southern Alberta is semiarid, with strong chinook winds (> $100 \mathrm{~km} \mathrm{hr}^{-1}$ ) that may carry particulate matter, and embedded VAs, downwind of feedlots.

Five of six VAs showed significantly $(P<0.001)$ greater median concentrations in feedlot environs than irrigation conveyances: CTC, 277 vs. $25 \mathrm{ng} \mathrm{L}^{-1}$; TYL, 42 vs. $2.5 \mathrm{ng} \mathrm{L}^{-1}$; MON, 436 vs. $2.5 \mathrm{ng} \mathrm{L}^{-1}$, ERY, 9.9 vs. $5.6 \mathrm{ng} \mathrm{L}^{-1}$, and TC, $515 \mathrm{vs} .56 \mathrm{ng} \mathrm{L}^{-1}$. The exception was SMZ, where there was no significant difference $(P=0.92)$ between feedlot environs $\left(\tilde{X}=6 \mathrm{ng} \mathrm{L}^{-1}\right)$ and irrigation conveyances $\left(\tilde{X}=5.5 \mathrm{ng} \mathrm{L}^{-1}\right)$. These VA concentrations were similar to previously reported values from agricultural settings (Bak and Bjorklund, 2014; Couperus et al. 2016; Jaimes-Correa et al., 2015; Sandoz et al., 2018). The only comparative study in Alberta (Forrest et al. 2011) analyzed a total of 247 water samples in 2005-06 from 23 streams identified as having predominantly agricultural activities in their watersheds. Five VAs common to our study were quantified: CTC, SMZ, MON, LIN, and ERY. Their detection frequencies vs. irrigation conveyances in our study were similar for SMZ (8 vs. $4 \%$ ) and LIN (1.2\% vs. zero), but much lower for CTC (0.4 vs. $94 \%)$, somewhat lower for ERY (0.8 vs. 18\%), and higher for MON (34 vs. 10\%). However, their MDLs were $10 \mathrm{ng}$ $\mathrm{L}^{-1}$ for CTC, LIN, and ERY, and $2 \mathrm{ng} \mathrm{L^{-1 }}$ for SMZ and MON, compared to $2.5 \mathrm{ng} \mathrm{L}^{-1}$ in our study. Maximum concentrations reported by Forrest et al. (2011) were higher than corresponding concentrations in our irrigation conveyances for MON (843 vs. $31 \mathrm{ng} \mathrm{L}^{-1}$ ), and LIN (18 $\mathrm{ng} \mathrm{L}^{-1}$ vs. <LOQ), but lower for CTC (20 vs. $\left.69 \mathrm{ng} \mathrm{L}^{-1}\right)$, SMZ (20 vs. $\left.33 \mathrm{ng} \mathrm{L}^{-1}\right)$, and ERY (10 vs. $\left.29 \mathrm{ng} \mathrm{L}^{-1}\right)$.

Previous research in southern Alberta has quantified CTC, SMZ and TYL concentrations in runoff (Table 6) from feedlot pen floors (Sura et al. 2015), compost windrows (Sura et al., 2016), and manured cropland (Amarakoon et al., 2014). Concentrations generally declined as the runoff source area moved away from feedlot pen floors. The value of composting as a manure management alternative was evident by large decreases in concentrations from 2-vs. 21-d old compost. Once manure was land applied (60 Mg ha-1 wet wt.), and especially when soil-incorporated, runoff concentrations fell further, by $\sim 2$ orders of magnitude compared to feedlot pen floors. Data from the current study (Table 6) shows further declines in CTC and SMZ concentrations in surface water from feedlot catch basins and adjacent creeks. However, there was

Page $21 / 36$ 
surprisingly little difference in TYL concentrations between runoff from manured cropland and surface water from irrigation conveyances. There were $\sim 5$ orders of magnitude difference in concentrations of CTC and SMZ in runoff from feedlot pen floors vs. surface water from irrigation conveyances. For TYL, the difference was $\sim 4$ orders of magnitude.

Table 6

Comparison of mean concentrations of CTC, SMZ, and TYL in runoff and surface water from studies conducted in the South Saskatchewan River Basin.

\begin{tabular}{|c|c|c|c|c|c|}
\hline \multirow[t]{2}{*}{ Matrix } & \multirow[t]{2}{*}{ Source location } & \multirow[t]{2}{*}{ Source details } & CTC & SMZ & TYL \\
\hline & & & \multicolumn{3}{|c|}{-ー-ー- $\mu \mathrm{g} \mathrm{L}^{-1}$} \\
\hline \multirow[t]{6}{*}{ Runoff water } & Feedlot pen floors ${ }^{a}$ & Bedding area & 5260 & 4570 & 540 \\
\hline & & Non-bedding area & 3130 & 3730 & 220 \\
\hline & Compost windrows ${ }^{\mathrm{b}}$ & Day $2^{c}$ & 2580 & 3600 & 4930 \\
\hline & & Day $21^{c}$ & 200 & 980 & 200 \\
\hline & Manured cropland ${ }^{d}$ & Surface applied & 59 & 3.9 & 0.02 \\
\hline & & Soil-incorporated & 15 & 2.6 & 0.06 \\
\hline \multirow[t]{6}{*}{ Surface water ${ }^{\mathrm{e}}$} & Feedlot environs & Catch basin & 0.82 & 0.008 & 0.14 \\
\hline & & Retention ponds/wetland & 0.39 & 0.007 & 0.15 \\
\hline & & Creek & 0.13 & $<\mathrm{LOQ}$ & 0.009 \\
\hline & Irrigation conveyances & Watershed return & 0.028 & 0.01 & 0.013 \\
\hline & & Infrastructure return & 0.024 & 0.02 & 0.013 \\
\hline & & Secondary & 0.027 & 0.007 & 0.017 \\
\hline \multicolumn{6}{|c|}{ asura et al. (2015). } \\
\hline \multicolumn{6}{|c|}{ bSura et al. (2016). } \\
\hline \multicolumn{6}{|c|}{ 'Start of composting = Day 0.} \\
\hline \multicolumn{6}{|c|}{ ddAmarakoon et al. (2014). } \\
\hline epresent study. & & & & & \\
\hline
\end{tabular}

While it is important to quantify the presence of VAs occurring in surface waters, it is arguably more critical to determine whether the compounds affect aquatic organisms, especially where diverse classes of VAs are detected simultaneously, exposing organisms and food webs to 'antibiotic cocktails' (Danner et al., 2019). While individual concentrations may be low, combined concentrations can result in significant toxicity to 
aquatic life because of synergistic effects (Grenni et al., 2018). Table 7 shows that overall, $37 \%$ of feedlot environ samples showed detection of six target VAs, while $17 \%$ showed detection of all seven. However, no creek samples showed detection of all seven target VAs, compared to $22-24 \%$ of catch basin and retention ponds/wetland samples, while $13 \%$ of creek samples showed detection of six VAs, compared to $43-49 \%$ of catch basin and retention ponds/wetland samples. Overall, for irrigation conveyance samples (2014-15 only), the majority of samples (77\%) exhibited detections of two VAs, with $21 \%$ three VAs, and only $1 \%$ four VAs (Table 7). The latter compared with $92 \%$ of feedlot environ samples exbibiting four or more VAs. Unlike detection frequency or median concentration parameters, the 'antibiotic cocktail' approach provided slight evidence of increased occurrence of VAs in watershed returns (23\% showing at least three VAs), compared to secondary sites ( $18 \%$ showing at least three VAs). It is noteworthy, that VAs concentrations in creeks and irrigation conveyances in our study were several orders of magnitude lower than the $1 \mu \mathrm{g} \mathrm{L}^{-1}$ inhibitory concentration for aquatic organisms (European Medicines Evaluation Agency, 2008; United States Food and Drug Administration, 1997), a threshold based on retrospective reviews of ecotoxicity data from environmental assessments.

Table 7

Number of target veterinary antimicrobials detected (> LOQ) in surface water samples from feedlot environs and irrigation conveyances (expressed as percent of total samples) SSRB, 2013-16.

\begin{tabular}{|c|c|c|c|c|c|c|c|}
\hline Sample source & Samples, $n$ & - & $-N$ & of & & & de \\
\hline & & 1 & 2 & 3 & 4 & 5 & 6 \\
\hline
\end{tabular}

Feedlot environs

\begin{tabular}{|lllllllll|}
\hline All & 114 & 0 & 3 & 5 & 13 & 25 & 37 & 17 \\
\hline Catch basins & 42 & 0 & 0 & 0 & 5 & 28 & 43 & 24 \\
\hline Retention pond/wetland & 41 & 0 & 0 & 0 & 12 & 17 & 49 & 22 \\
\hline Creek & 31 & 0 & 10 & 19 & 26 & 32 & 13 & 0 \\
\hline Irrigation conveyances (2014-15 only) a & & & & & & & \\
\hline All & 190 & 1 & 77 & 21 & 1 & 0 & 0 & 0 \\
\hline Secondary & 72 & 1 & 81 & 18 & 0 & 0 & 0 & 0 \\
\hline Infrastructure return & 62 & 2 & 74 & 21 & 3 & 0 & 0 & 0 \\
\hline Watershed return & 56 & 0 & 77 & 23 & 0 & 0 & 0 & 0 \\
\hline a2013 not included because TC not analyzed. & & & & & & \\
\hline
\end{tabular}

In surface water in Nebraska, Naderi Beni et al. (2020) detected only one VA (MON), prescribed to confined and grazing livestock at an adjacent farm. Other prescribed VAs (CTC, TYL, SMZ) were undetectable, while non-prescribed VAs (LIN, ERY) were detected. Of the seven VAs in our study, only two (TYL, MON) are used 
exclusively in veterinary medicine, while the remainder are used in both veterinary and human medicine. The detection of some classes of antimicrobials not used to treat livestock potentially indicated their production by endogenous soil bacteria, e.g. ERY (Schafhauser et al., 2018). In addition, ERY used in human therapy can attach to biosolids at wastewater treatment plants, and ultimately reach groundwater after land application (Yan et al., 2014). Biosolids from the City of Lethbridge are applied to local agricultural land and may eventually access irrigation conveyance returns. Thus, surface water contamination originating from veterinary products cannot always be distinguished from that arising from human medicine, as the same antimicrobials may be used throughout the one health continuum (Charuaud et al., 2019). In a rural Indiana stream, Bernot et al. (2013) reported that acetaminophen and caffeine concentrations of human origin were $\sim 1$ order of magnitude greater than veterinary pharmaceuticals SMZ and LIN.

\section{Conclusions}

We have shown the omnipresence of TC, and to a lesser extent CTC, in surface water of a high-intensity agroecosystem in southern Alberta. Detection frequencies and median concentrations were much lower for SMZ, TYL, and ERY. Monensin detection frequency and concentration was higher in feedlot environs than irrigation conveyances. Lincomycin was undetectable in irrigation conveyance water.

Our study highlights the challenge of linking environmental occurrence of VAs to local sources. While VAs concentrations may be low, especially in irrigation conveyances, environmental persistence may be a more important consideration in defining strategies for managing VAs in agroecosystems to reduce risk, and elucidating their roles in antimicrobial resistance. It is evident from our work that research gaps exist and further investigation on environmental fate of VAs is warranted, especially in high-intensity agroecosystems regions such as the South Saskatchewan River Basin.

\section{Declarations}

\section{Acknowledgements}

The assistance of Andrew Olson, Kyle Shade, Krysty Munns, Shaun Cook, Lisa Tymensen, Lynda Miedema, Jenna Cantin, Kerry Peru, and Jonathan Bailey in sample collection and analyses is gratefully acknowledged. Courtney Stamm and Sherry Hannon, Feedlot Health Management Services, Okotoks, Alberta, facilitated sampling of feedlot environs. Irrigation conveyance sampling would not have been possible without the support of the Alberta Irrigation Council and the Alberta Irrigation Projects Association. We thank Joe Kendall for input on a draft of this manuscript. This work was supported by Agriculture and Agri-Food Canada A-Base funding and the Beef Cattle Research Council - Beef Science Cluster.

\section{Funding}

This work was supported by Agriculture and Agri-Food Canada A-Base funding (J-001407 - Transport of Hormones in Surface Runoff) and the Beef Cattle Research Council - Beef Science Cluster (J-001966 - ASC01 Beef Cluster Activity) received by Francis J. Larney. 


\section{Competing Interests}

The authors declare no financial or non-financial or completing interests that are relevant to the content of this research article.

\section{Author Contributions}

All authors contributed to the study conception and design. Sample analysis and data collection were performed by Srinivas Sura. Data analysis was performed by Francis J. Larney and Srinivas Sura. The first draft of the manuscript was written by Francis J. Larney and revisions were incorporated by Srinivas Sura. All authors commented on earlier versions of the manuscript. All authors read and approved the final manuscript.

\section{Availability of Data and Materials}

Not applicable

\section{Ethical Approval}

Not applicable

\section{Consent to Participate}

Not applicable

\section{Consent to Publish}

Not applicable

\section{References}

1. Acharya MP, Grant Kalischuk R, Klein KK, Bjornlund H (2007) Do water contamination reports influence water use practices on feedlot farms and rural households in southern Alberta? Can Water Resour $\mathrm{J}$ 32:213-226

2. Alberta Agriculture and Forestry (2021) Alberta Irrigation Information 2020. https://open.alberta.ca/publications/3295832

3. Alberta Agriculture and Forestry (2020) Alberta's irrigation - A strategy for the future $-2018 / 2019$ strategy measures. https://open.alberta.ca/publications/albertas-irrigation-a-strategy-for-the-futurestrategy-measures

4. Alberta Agriculture and Rural Development (2008) A guide to the legislation for confined feeding operations (CFOs) and manure management requirements for all agricultural operations in Alberta. 2008 Reference Guide, Agricultural Operation Practices Act (AOPA). https://www.nrcb.ca/public/download/files/97521 
5. Alberta Climate Information Service (2020) Current and historical Alberta weather station data viewer. http://agriculture.alberta.ca/acis/weather-data-viewer.jsp

6. Alberta Environment (2006) Approved water management plan for the South Saskatchewan River Basin (Alberta). https://open.alberta.ca/publications/0778546209

7. Alberta Environment (2007) Aquatic and riparian condition assessment of the South Saskatchewan River Basin. https://open.alberta.ca/dataset/274d8f92-9dde-4fb9-85c7c783fadb5969/resource/93661e85-3cd3-4d0f-a6f9-b9c8c20f6ee0/download/ aquaticriparianassessment-ssrb-jun2007.pdf

8. Almeida CMR, Basto MCP, Araújo JL, Carvalho PN, Mucha AP (2013) Potential of constructed wetlands microcosms for the removal of veterinary pharmaceuticals from livestock wastewater. Bioresour Technol 134:412-416

9. Alonso LL, Demetrio PM, Capparelli AL, Marino DJG (2019) Behavior of ionophore antibiotics in aquatic environments in Argentina: The distribution on different scales in water courses and the role of wetlands in depuration. Environ Internat 133:105144

10. Amarakoon ID, Sura S, Zvomuya F, Cessna AJ, Larney FJ, McAllister TA (2016) Dissipation of antimicrobials in a seasonally frozen soil after beef cattle manure application. J Environ Qual 45:1644-1651

11. Amarakoon ID, Zvomuya F, Cessna AJ, Degenhardt D, Larney FJ, McAllister TA (2014) Runoff losses of excreted chlortetracycline, sulfamethazine, and tylosin from surface-applied and soil-incorporated beef cattle feedlot manure. J Environ Qual 43:549-557

12. Azanu D, Mortey C, Darko G, Weisser JJ, Styrishave B, Abaidoo R (2016) Uptake of antibiotics from irrigation water by plants. Chemosphere 157:107-114

13. Bak SA, Björklund E (2014) Occurrence of ionophores in the Danish environment. Antibiotics 3:564571

14. Beaulieu MS, Bédard F (2003) A geographic profile of Canadian livestock, 1991-2001. Agriculture and Rural Working Paper Series, No. 62, Statistics Canada. http://www.statcan.ca/english/research/21601-MIE/21-601-MIE2003062.pdf

15. Bernot MJ, Smith L, Frey J (2013) Human and veterinary pharmaceutical abundance and transport in a rural central Indiana stream influenced by confined animal feeding operations (CAFOs). Sci Tot Environ 445-446:219-230

16. Byrne J, Kienzle S, Johnson D, Duke G, Gannon V, Selinger B, Thomas J (2006) Current and future water issues in the Oldman river basin of Alberta, Canada. Water Sci Technol 53:327-334

17. Cessna AJ, Elliott JA, Tollefson L, Nicholaichuk W (2001) Herbicide and nutrient transport from an irrigation district into the South Saskatchewan River. J Environ Qual 30:1796-1807

18. Cessna AJ, Kuchta SL, Waiser M, Brua RB, Bailey J (2020) Persistence of the antimicrobials lincomycin, chlortetracycline, and sulfamethazine in prairie wetlands. J Environ Qual 49:236-245

19. Charest J, Olson B, Kalischuk A, Gross D (2014) Water quality in Alberta's irrigation districts 2011 to 2015: 2013 Progress Report. Alberta Agriculture and Forestry, Lethbridge, AB. 156 pp 
20. Charest J, Olson B, Kalischuk A, Gross D (2015) Water quality in Alberta's irrigation districts 2011 to 2015: 2014 Progress Report. Alberta Agriculture and Forestry, Lethbridge, AB. 215 pp

21. Charuaud L, Jardé E, Jaffrézic A, Liotaud M, Goyat Q, Mercier F, Le Bot B (2019) Veterinary pharmaceutical residues in water resources and tap water in an intensive husbandry area in France. Sci Total Environ 664:604-615

22. Chattopadhyay MK (2014) Use of antibiotics as feed additives: a burning question. Front Microbiol 5:334

23. Choi YJ, Kim LH, Zoh KD (2016) Removal characteristics and mechanism of antibiotics using constructed wetlands. Ecol Eng 91:85-92

24. Couperus NP, Pagsuyoin SA, Bragg LM, Servos MR (2016) Occurrence, distribution, and sources of antimicrobials in a mixed-use watershed. Sci Total Environ 541:1581-1591

25. Daghrir R, Drogui $P$ (2013) Tetracycline antibiotics in the environment: a review. Environ Chem Lett 11:209-227

26. Danner MC, Robertson A, Behrends V, Reiss J (2019) Antibiotic pollution in surface fresh waters: Occurrence and effects. Sci Tot Environ 664:793-804

27. European Medicines Evaluation Agency (2008) EMEA/CVMP/ERA/418282/2005-rev.1consultation. Technical Paper, pp. 1-65

28. Felis E, Kalka J, Sochacki A, Kowalska K, Bajkacz S, Harnisz M, Korzeniewska E (2020) Antimicrobial pharmaceuticals in the aquatic environment - occurrence and environmental implications. Eur $\mathrm{J}$ Pharmacol 866:172813

29. Forrest F, Lorenz K, Thompson T, Keenliside J, Kendall J, Charest J (2011) A scoping study of livestock antimicrobials in agricultural streams of Alberta. Can Water Resour J 36:1-16

30. Gannon VPJ, Duke GD, Thomas JE, Van Leeuwen J, Byrne J, Johnson D, Kienzle SW, Little J, Graham T, Selinger B (2005) Use of in-stream reservoirs to reduce bacterial contamination of rural watersheds. Sci Tot Environ 348:19-31

31. Grenni P, Ancona V, Barra Caracciolo A (2018) Ecological effects of antibiotics on natural ecosystems: a review. Microchem J 136:25-39

32. Heuer H, Schmitt H, Smalla K (2011) Antibiotic resistance gene spread due to manure application on agricultural fields. Curr Opin Microbiol 14:236-243

33. Hyland R, Byrne J, Selinger B, Graham T, Thomas J, Townshend I, Gannon V (2003) Spatial and temporal distribution of fecal indicator bacteria within the Oldman River Basin of southern Alberta, Canada. Water Qual Res J Can 38:15-32

34. Ilyas H, Masih I, van Hullebusch ED (2020) Pharmaceuticals' removal by constructed wetlands: A critical evaluation and meta-analysis on performance, risk reduction, and role of physicochemical properties on removal mechanisms. J Water Health 18:253-291

35. Irrigation Water Management Study Committee (2002) Economic opportunities and impacts. South Saskatchewan River basin: Irrigation in the 21st century, vol 5. Alberta Irrigation Projects Assoc., Lethbridge, $A B$ 
36. Jaffrézic A, Jardé E, Soulier A, Carrera L, Marengue E, Cailleau A, Le Bot B (2017) Veterinary pharmaceutical contamination in mixed land use watersheds: from agricultural headwater to water monitoring watershed. Sci Total Environ 609:992-1000

37. Jaimes-Correa JC, Snow DD, Bartelt-Hunt SL (2015) Seasonal occurrence of antibiotics and a beta agonist in an agriculturally-intensive watershed. Environ Pollut 205:87-96

38. Johnson JY, Thomas JE, Graham TA, Townshend I, Byrne J, Selinger B, Gannon VPJ (2003) Prevalence of Escherichia coli 0157:H7 and Salmonella spp. in surface waters of southern Alberta and its relation to manure sources. Can J Microbiol 49:326-335

39. Jokinen CC, Edge TA, Koning W, Laing CR, Lapen DR, Miller J, Mutschall S, Scott A, Taboada EN, Thomas JE, Topp E, Wilkes G, Gannon VPJ (2012) Spatial and temporal drivers of zoonotic pathogen contamination of an agricultural watershed. J Environ Qual 41:242-252

40. Kim K, Owens G, Kwon S, So K, Lee D, Ok YS (2011) Occurrence and environmental fate of veterinary antibiotics in the terrestrial environment. Water Air Soil Pollut 214:163-174

41. Kolok AS, Sellin Jeffries MK, Knight L, Snow DD, Bartelt-Hunt SL (2014) The hourglass: A conceptual framework for the transport of biologically active compounds from agricultural landscapes. J Amer Water Resour Assoc 50:266-274

42. Kümmerer K (2009) Antibiotics in the aquatic environment - A review - Part I. Chemosphere 75:417434

43. Kuchta SL, Cessna AJ, Elliott JA, Peru KM, Headley JV (2009) Transport of lincomycin to surface and ground water from manure-amended cropland. J Environ Qual 38:1719-1727

44. Landers TF, Cohen B, Wittum TE, Larson EL (2012) A review of antibiotic use in food animals: Perspective, policy, and potential. Public Health Rep 127:4-22

45. Lapworth DJ, Baran N, Stuart ME, Ward RS (2012) Emerging organic contaminants in groundwater: A review of sources, fate and occurrence. Environ Pollut 163:287-303

46. Leung HW, Jin L, Wei S, Tsui MMP, Zhou B, Jiao L, Cheung PC, Chun YK, Murphy MB Lam PKS 2013 Pharmaceuticals in tap water: human health risk assessment and proposed monitoring framework in China.Environ Health Perspect121:839-846

47. Li Y, Zhu G, Ng WJ, Tan SK (2014) A review on removing pharmaceutical contaminants from wastewater by constructed wetlands: design, performance and mechanism. Sci Total Environ 468469:908-932

48. Little JL, Nolan SC, Casson JP, Olson BM (2007) Relationships between soil and runoff phosphorus in small Alberta watersheds. J Environ Qual 36:1289-1300

49. Little JL, Saffran KA, Fent L (2003) Land use and water quality relationships in the lower Little Bow River watershed, Alberta, Canada. Water Qual Res J Can 38:563-584

50. McEachran AD, Blackwell BR, Hanson JD, Wooten KJ, Mayer GD, Cox SB, Smith PN (2015) Antibiotics, bacteria, and antibiotic resistance genes: aerial transport from cattle feed yards via particulate matter. Environ Health Perspect 123:337-343 
51. Miller JJ, Handerek BP, Beasley BW, Olson ECS, Yanke LJ, Larney FJ, McAllister TA, Olson BM, Selinger LB, Chanasyk DS, Hasselback P (2004) Quantity and quality of runoff from a beef cattle feedlot in southern Alberta. J Environ Qual 33:1088-1097

52. Mompelat S, Le Bot B, Thomas O (2009) Occurrence and fate of pharmaceutical products and byproducts, from resource to drinking water. Environ Int 35:803-814

53. Naderi Beni N, Snow DD, Berry ED, Mittelstet AR, Messer TL, Bartelt-Hunt S (2020) Measuring the occurrence of antibiotics in surface water adjacent to cattle grazing areas using passive samplers. Sci Total Environ 726:138296

54. Paterson Earth \& Water Consulting (2015) Economic value of irrigation in Alberta. Prepared for the Alberta Irrigation Projects Association. Lethbridge, AB. 137 pp

55. Province of Alberta (1999) Water act. Alberta Queen's Printer, Edmonton, AB

56. Sandoz MA, Wooten KJ, Clendening SL, Hensley LL, Smith LR, Smith PN (2018) Transport mechanisms for veterinary pharmaceuticals from beef cattle feedyards to wetlands: Is aerial deposition a contributing source? Agric Ecosyst Environ 252:14-21

57. Sarmah AK, Meyer MT, Boxall ABA (2006) A global perspective on the use, sales, exposure pathways, occurrence, fate and effects of veterinary antibiotics (VAs) in the environment. Chemosphere 65:725759

58. Schafhauser BH, Kristofco LA, de Oliveira CMR, Brooks BW (2018) Global review and analysis of erythromycin in the environment: occurrence, bioaccumulation and antibiotic resistance hazards. Environ Pollut 238:440-451

59. Schindler DW, Donahue WF (2006) An impending water crisis in Canada's western prairie provinces. Proc Natl Acad Sci 103:7210-7216

60. Statistics Canada (2016) 2016 census of agriculture. https://www.statcan.gc.ca/eng/ca2016

61. Statistics Canada (2006) A geographical profile of livestock manure production in Canada, 2006. https://www150.statcan.gc.ca/n1/pub/16-002-x/2008004/article/10751-eng.htm

62. Sura S, Degenhardt D, Cessna AJ, Larney FJ, Olson AF, McAllister TA (2015) Transport of three veterinary antimicrobials from feedlot pens via simulated rainfall runoff. Sci Total Environ 521522:191-199

63. Sura S, Degenhardt D, Cessna AJ, Larney FJ, Olson AF, McAllister TA (2016) Transport of three antimicrobials in runoff from windrows of composting beef cattle manure. J Environ Qual 45:494-502

64. Systat Software Inc (2020) SigmaPlot for Windows Version 14.5. Systat Software Inc., San Jose, CA

65. Tasho RP, Cho JY (2016) Veterinary antibiotics in animal waste, its distribution in soil and uptake by plants: A review. Sci Total Environ 563-564:366-376

66. Tymensen L, Booker CW, Hannon SJ, Cook SR, Zaheer R, Read R, McAllister TA (2017) Environmental growth of Enterococci and Escherichia coli in feedlot catch basins and a constructed wetland in the absence of fecal input. Environ Sci Technol 51:5386-5395

67. United States Food and Drug Administration (1997) Retrospective review of ecotoxicity data submitted in environmental assessments for public display. Docket No. 96N-0057. 
68. USDA (2020) Cattle inventory. https://www.nass.usda.gov/Surveys/Guide_to_NASS_ Surveys/Cattle_Inventory/

69. Van Boeckel TP, Brower C, Gilbert M, Grenfell BT, Levin SA, Robinson TP, Teillant A, Laxminarayan R (2015) Global trends in antimicrobial use in food animals. Proc Natl Acad Sci 112:5649-5654

70. Vymazal J (2011) Constructed wetlands for wastewater treatment: five decades of experience. Environ Sci Technol 45:61-69

71. Yan Q, Gao X, Chen YP, Peng XY, Zhang YX, Gan XM, Zi CF, Guo JS (2014) Occurrence, fate and ecotoxicological assessment of pharmaceutically active compounds in wastewater and sludge from wastewater treatment plants in Chongqing, the Three Gorges Reservoir Area. Sci Total Environ 470471:618-630

72. Zhou LJ, Ying GG, Liu S, Zhang RQ, Lai HJ, Chen ZF, Pan CG (2013) Excretion masses and environmental occurrence of antibiotics in typical swine and dairy cattle farms in China. Sci Total Environ 444:183-195

\section{Figures}

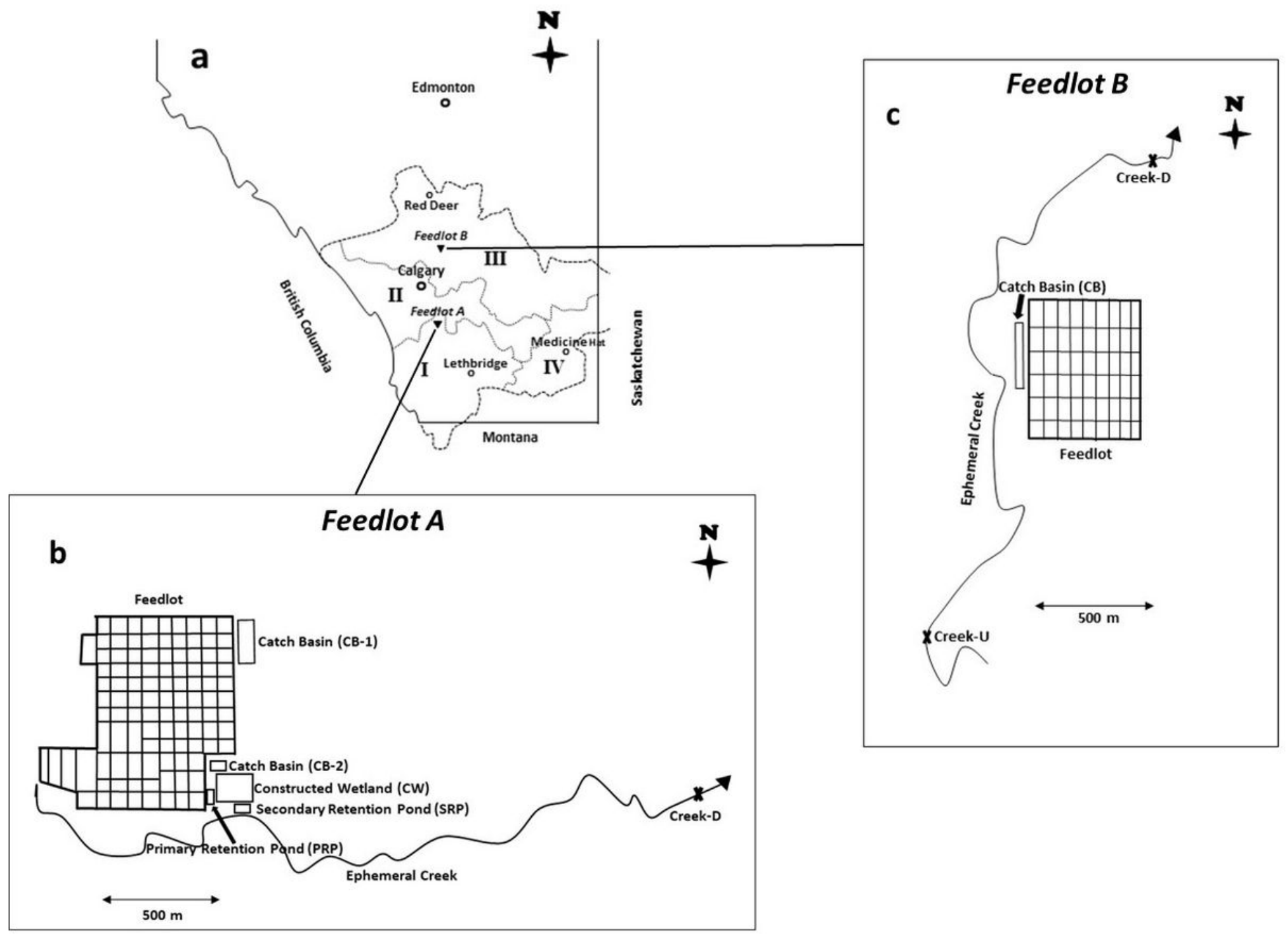


Figure 1

a Southern Alberta showing the South Saskatchewan River Basin comprising of (I) Oldman River; (II) Bow River; (III) Red Deer River; and (IV) South Saskatchewan River sub-basins, and relative locations of Feedlots A and B; b Feedlot A showing 6 water sampling sites: Catch Basin 1 (CB-1), Catch Basin 2 (CB-2), Primary Retention Pond (PRP), Constructed Wetland (CW), Secondary Retention Pond (SRP), and Downstream Creek (Creek-D); c Feedlot B showing 3 water sampling sites: Catch Basin (CB), Downstream Creek (Creek-D), and Upstream Creek (Creek-U).

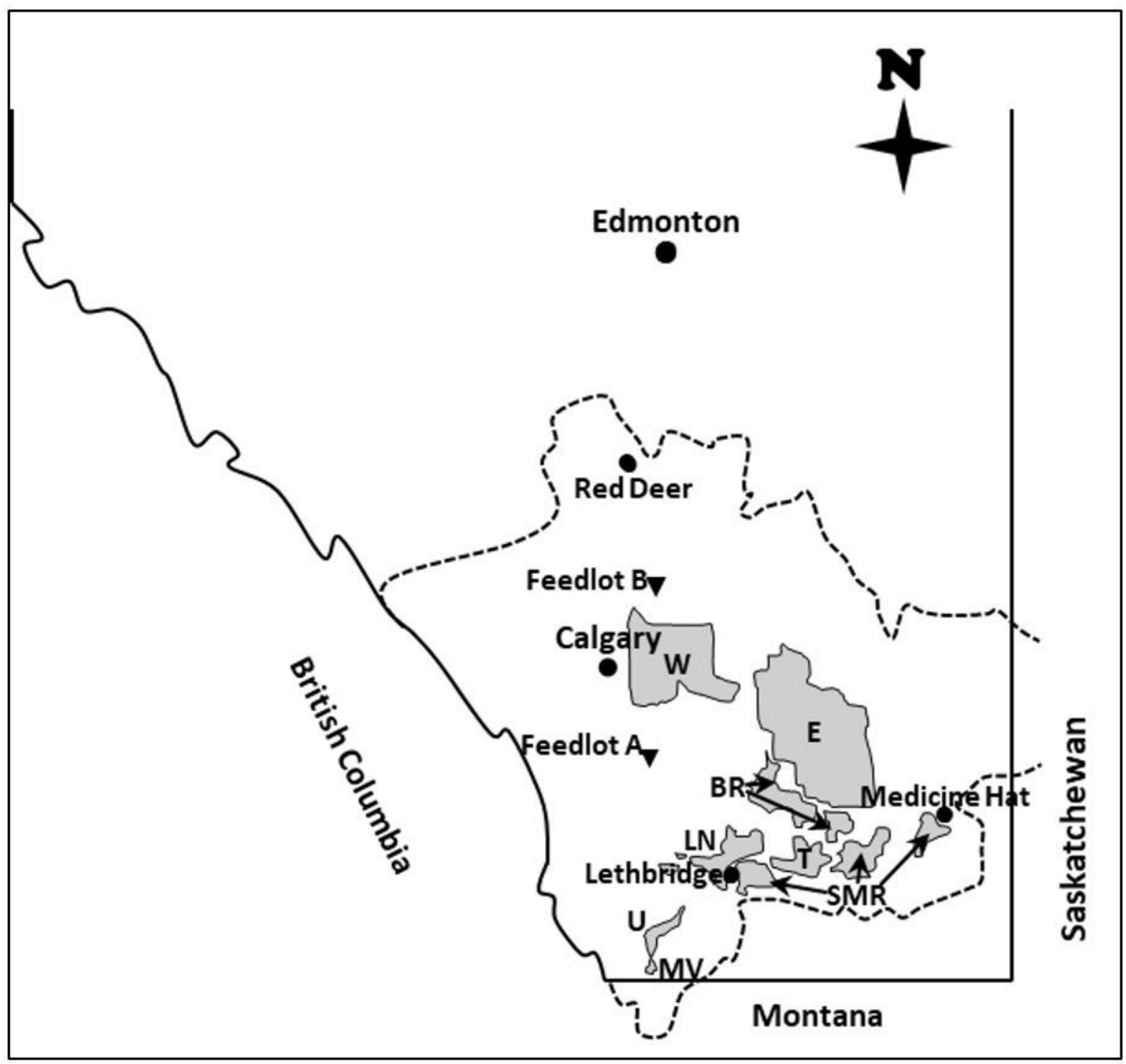

Figure 2 
Southern Alberta showing irrigation districts (LN, Lethbridge Northern; SMR, St. Mary River; T, Taber; BR, Bow River; E, Eastern; W, Western; U, United; MV, Mountain View) sampled within the South Saskatchewan River Basin (dashed line boundary). Feedlots A and B locations included for reference.

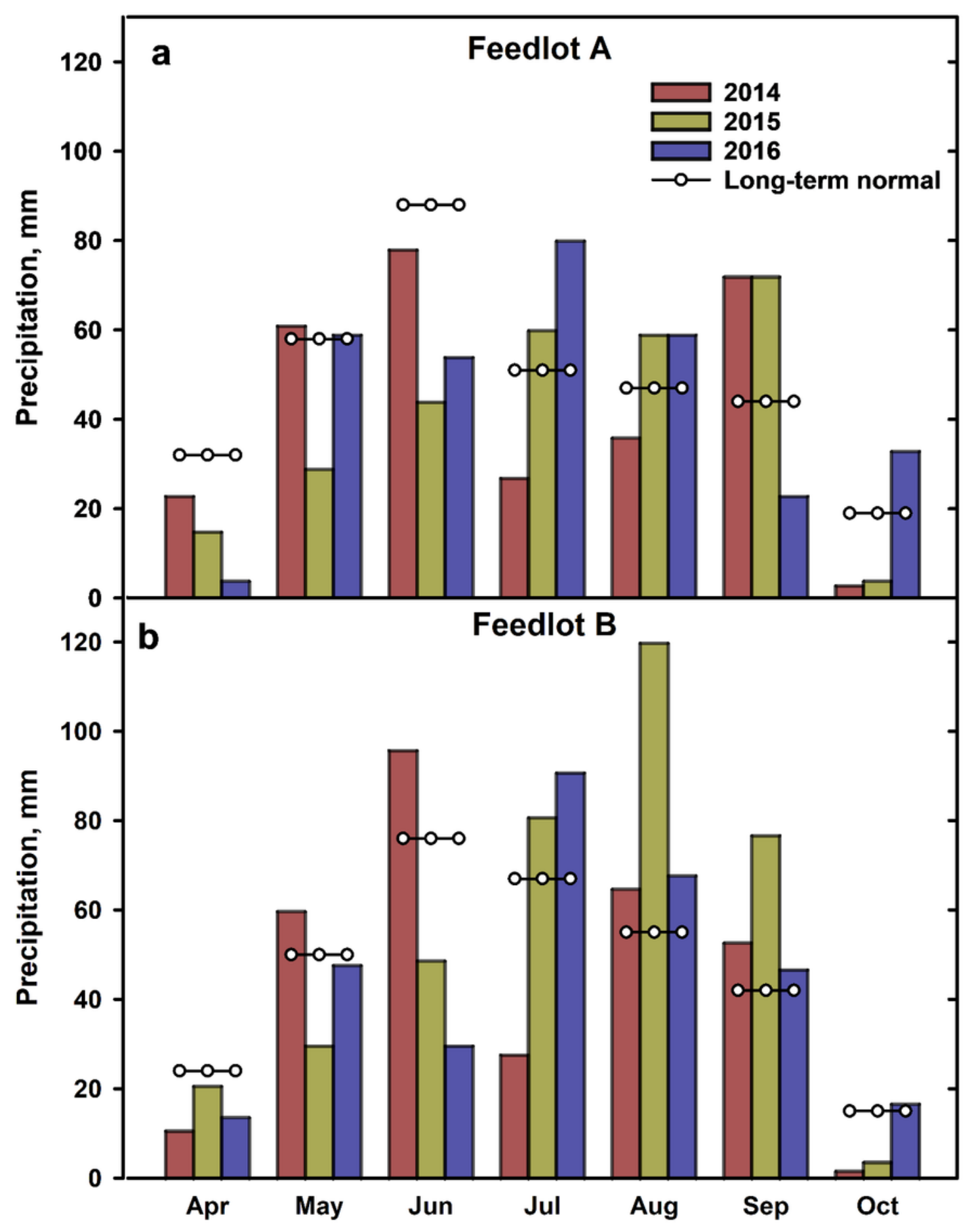

Figure 3

Monthly precipitation (April-October, 2014, 2015, 2016; long-term normal) at a Feedlot A and b Feedlot B. Source: Alberta Climate Information Service stations located $14 \mathrm{~km}$ from Feedlot A and $12.8 \mathrm{~km}$ from 
Feedlot B (http://agriculture.alberta.ca/acis/weather-data-viewer.jsp).

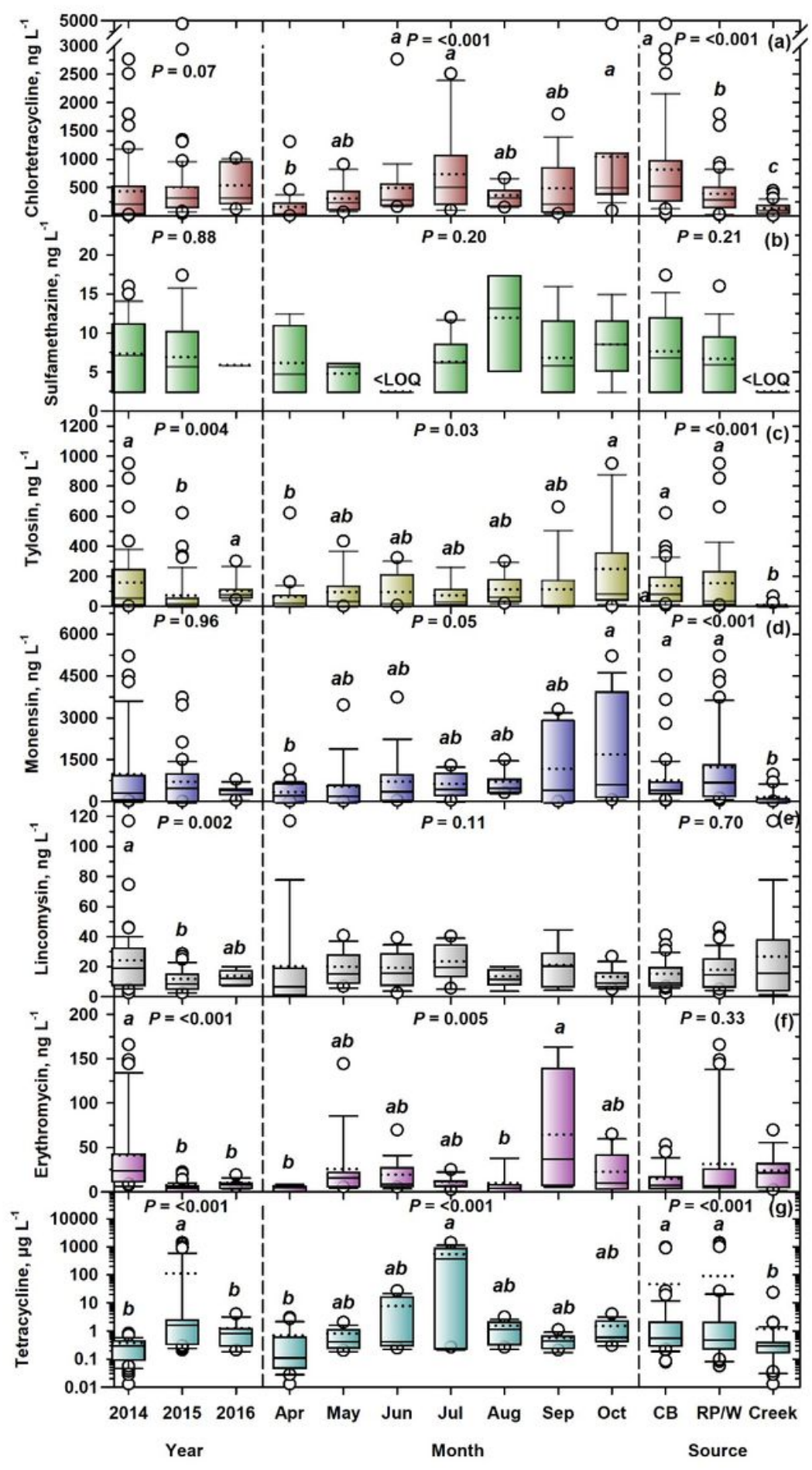

Figure 4

Box plots for concentrations of veterinary antimicrobials in feedlot environs: a CTC; b SMZ; c TYL; $\mathbf{d}$ MON; e LIN; f ERY; and $\mathbf{g} T C$, grouped by sampling year, sampling month, and sample source (CB = catch basins at Feedlots $A$ and $B ; R P / W$ = retention pond/wetland: PRP, CW, and SRP at Feedlot $A ;$ Creek = Creek-D at Feedlot A, Creek-U and Creek-D at Feedlot B). Within boxes, a solid horizontal line marks the median 
concentration. A dotted horizontal line marks the mean concentration. The lower boundary of the box indicates the 25th percentile, and the upper boundary the 75th percentile. Whiskers (error bars) indicate 10th and 90th percentiles. Circle symbols indicate outliers falling outside the 10th and 90th percentiles. $P$ values are presented for Kruskal-Wallis tests on each group of samples. When significant $(P<0.05)$, box plots within groups with different letters have significantly different median concentrations based on Dunn's test.

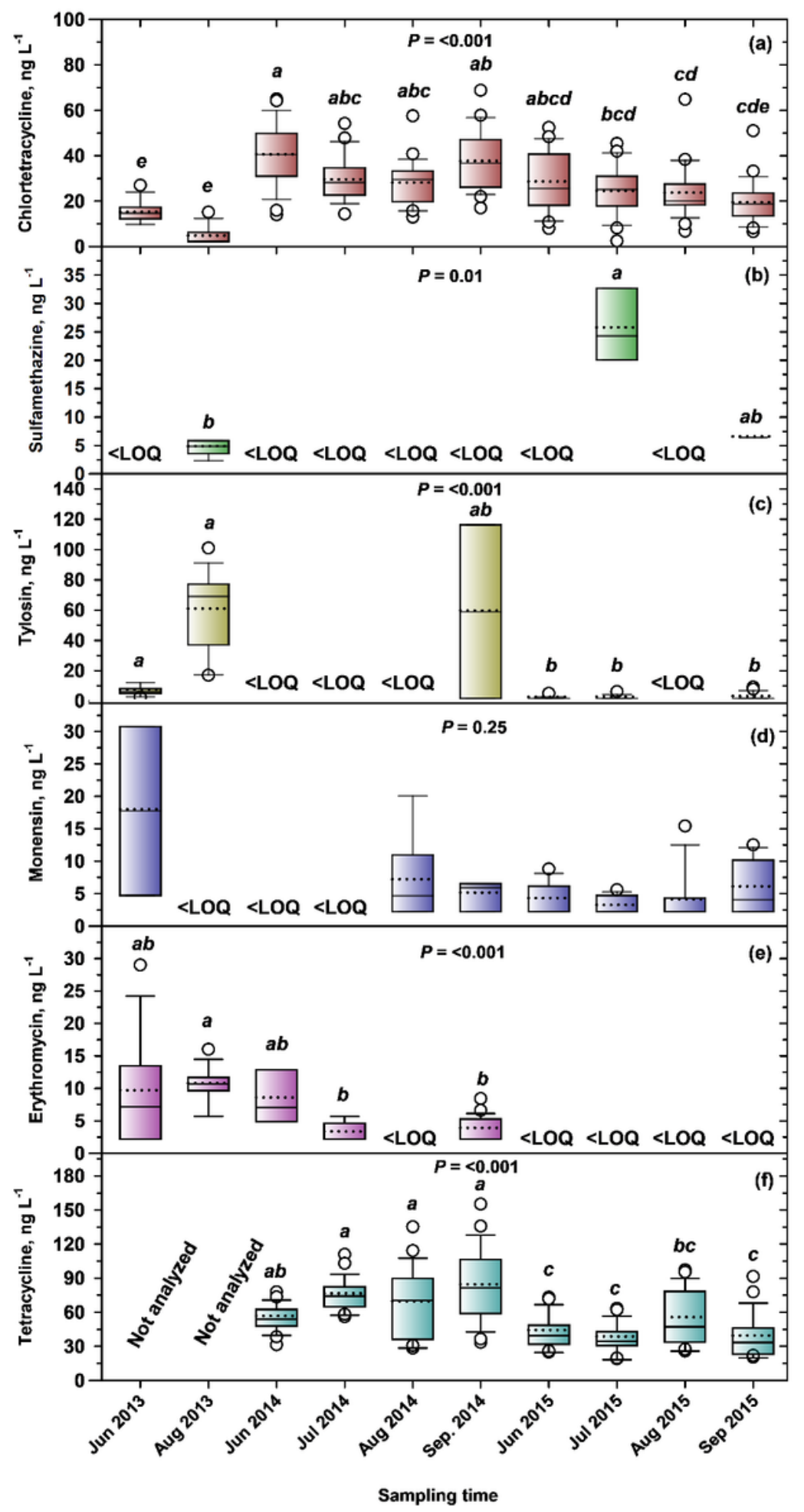

Figure 5 
Box plots for concentrations of veterinary antimicrobials in irrigation conveyances: a CTC; b SMZ; c TYL; $\mathbf{d}$ MON; e ERY; and f TC, grouped by sampling time. Within boxes, a solid horizontal line marks the median concentration. A dotted horizontal line marks the mean concentration. The lower boundary of the box indicates the 25th percentile, and the upper boundary the 75th percentile. Whiskers (error bars) indicate 10th and 90 th percentiles. Circle symbols indicate outliers falling outside the 10th and 90th percentiles. $P$ values are presented for Kruskal-Wallis tests. When significant $(P<0.05)$, box plots with different letters have significantly different median concentrations based on Dunn's test.

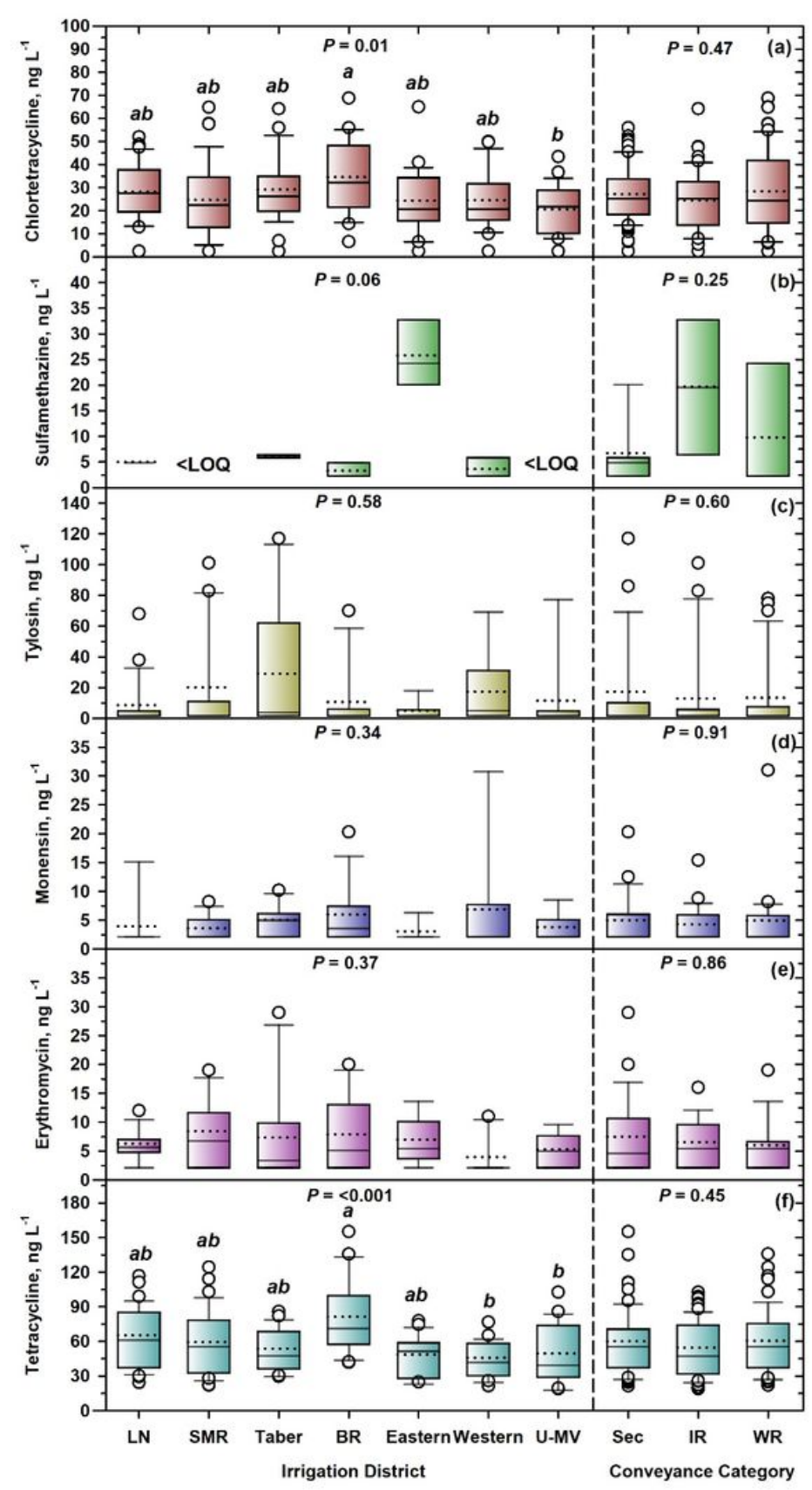

Figure 6 
Box plots for concentrations of veterinary antimicrobials in irrigation conveyances: a CTC; b SMZ; c TYL; $\mathbf{d}$ MON; e ERY; and f TC, grouped by irrigation district (LN = Lethbridge Northern; SMR = St. Mary River; BR = Bow River; U-MV = United-Mountain View), and conveyance category ( $\mathrm{Sec}=$ secondary; IR = infrastructure return; WR = watershed return). Within boxes, a solid horizontal line marks the median concentration. A dotted horizontal line marks the mean concentration. The lower boundary of the box indicates the 25th percentile, and the upper boundary the 75th percentile. Whiskers (error bars) indicate 10th and 90th percentiles. Circle symbols indicate outliers falling outside the 10th and 90th percentiles. $P$ values are presented for Kruskal-Wallis tests on each group of samples. When significant $(P<0.05)$, box plots within groups with different letters have significantly different median concentrations based on Dunn's test.

\section{Supplementary Files}

This is a list of supplementary files associated with this preprint. Click to download.

- Supplementarymaterial.docx 